\title{
NBSIR 73-267 \\ Report of Fire Tests on Flexible Connectors in HVAC Systems
}

Lionel A. Issen

Center for Building Technology Institute for Applied Technology National Bureau of Standards

Washington, D. C. 20234

July 1973

Final Report

\section{Prepared for}

American Iron \& Steel Institute

New York, New York 10017 



\section{REPORT OF FIRE TESTS ON FLEXIBLE} CONNECTORS IN HVAC SYSTEMS

Lionel A. Issen

Center for Buildirig Technology Institute for Applied Technology National Bureau of Standards

Washington, D. C. 20234

July 1973

Final Report

Prepared for

American Iron \& Steel Institute

New York, New York 10017

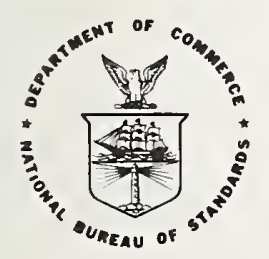

U. S. DEPARTMENT OF COMMERCE, Frederick B. Dent, Secretary

NATIONAL BUREAU OF STANDARDS, Richard W. Roberts, Director 

REPORT OF FIRE TESTS

ON

FLEXIBLE CONNECTORS IN HVAC SYSTEMS

\section{Abstract}

The contemporary high rise building with its central air conditioning system and high content of synthetic materials presents a potentially higher fire and smoke hazard than those erected prior to 1950 . The fire penetration and the transportation of fire, hot gases, noxious fumes and smoke through the duct system is an important factor affecting the designers' and building code concept of compartmentalization and life safety of occupants. Since air ducts penetrate fire barriers, the duct materials, the flexible connectors between the ducts, and the terminal units are all important elements that can affect the actual fire endurance of the fire barrier.

Flexible connectors made of four different materials (aluminum, galvanized steel, glass fiber and woven glass fiber) and two attachment techniques were subjected to fire tests which conformed to the Standard Method of Fire Tests for Building Constructions and Materials, ASTM E 119. The results show that in order to maintain the integrity of a fire barrier penetrated by a duct or flexible connector, the duct and connector must maintain their integrity for the period of the fire exposure, the connectors must remain tightly attached to the duct, and the penetrations through the fire barrier must be suitably blocked (fire stopped) at the edge of 
the opening. The tests also showed that rubber and plastic components in the terminal units can produce significant amounts of irritating smoke which can spread into the room and hence to other parts of the buildings. Key Words: Aluminum; ductwork; fabric; fire tests; glass fiber; high rise buildings; HVAC systems; steel; terminal units. 


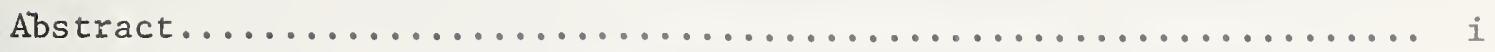

LIST OF ILLUSTRATIONS. .......................... v v

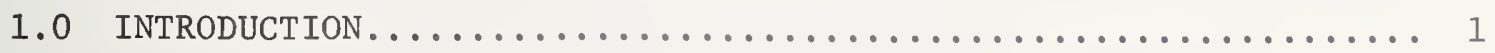

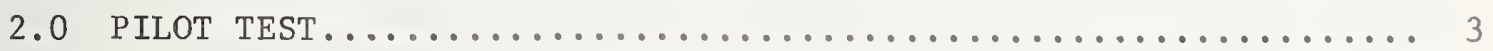

2.1 Description of Test (NBS Test 512)................. 3

2.2 Furnace Closure........................... 4

2.3 Flexible Connectors........................... 4

2.4 Instrumentation........................... 5

3.0 EVALUATION TEST.............................. 6

3.1 Description of Test (NBS Test 516 ).................. 6

3.2 Furnace Closure............................ 8

3.3 Flexible Connectors.......................... 8

3.4 Instrumentation........................... 10

3.4.1 Glass Fiber Connectors..................... 11

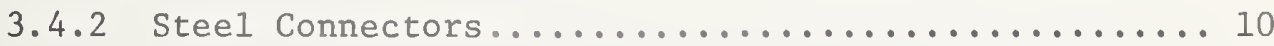



4.1 Pilot Test (NBS Test 512$) \ldots \ldots \ldots \ldots \ldots \ldots \ldots \ldots \ldots \ldots \ldots \ldots$

4.1 .2 General Observations...................... 11

4.2 Evaluation Test (NBS Test 516$) \ldots \ldots \ldots \ldots \ldots \ldots \ldots \ldots \ldots$

4.2.1 Temperature Observations.................... 12

4.2.1.1 Furnace Temperatures................ 12

4.2.1.2 Connector Assembly Temperatures......... 12

4.2.1.3 Glass Fiber Connectors.............. 12

4.2.1.4 Steel Connector Temperatures........... 14 


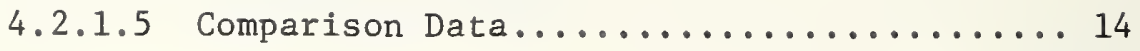

5.0 DISCUSSION AND SUMMARY OF RESULTS.................. 15

5.1 Temperature and Fire Endurance................... 15

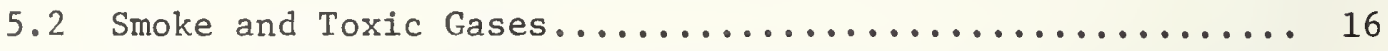

5.3 Comparison of Square and Round Ducts.............. 17

5.4 Performance Considerations...................... 18

6.0 ACKNOWLEDGEMENT................................. 19

APPENDIX A: Observation During Pilot Test (NBS 512)........... 20

APPENDIX B: Observation During Evaluation Test (NBS 516)........ 22

BIBLIOGRAPHY..................................... 25 


\section{LIST OF ILLUSTRATIONS}

$\underline{\text { Figure }}$

Test 512 Typical Layout Showing Flexible Connector Assembly

2

Test 512 View of Raised Furnace Closure

3 Test 512 View of Steel Connectors, Showing the Vinyl Covering and Attachment to the Duct

4 Test 512 View of Aluminum Connector Showing Viny1 Cover and Attachment to the Duct

Test 512 View of Steel Flexible Connectors at Terminal Unit

6

Test 512 View of Aluminum Flexible Connector at Terminal Unit

7 Test 512 Architectural Enclosures in Place

8 Test 512 Aluminum Flexible Connector (Note method of blocking penetrations through closure.)

9 Test 512 Thermocouple Layout

10 Test 516 Top View of Furnace Showing Flexible Connector Test Layout

11 Test 516 Construction and Thermocouple Details for Glass Fiber Flexible Connectors

12 Test 516 Construction Details for Steel Flexible Connectors

13 Flange Plates

14 Penetration Through Closure

15 Typical Duct Showing Glass Fiber Blanket and Connector Function Point

16 Test 516 Thermocouple Layout for Steel Flexible Connector and ONYP Terminal Units

17 Test 516 Furnace Temperatures

Test 5165 Inch Glass Fiber - Temperatures Along Connector and Architectural Enclosure 
20 Test 5165 Inch Glass Fiber - Air Temperature Architectural Enclosure

Test 5165 Inch Woven Glass Fabric - Temperatures Along Corridor

Test 5165 Inch Woven Glass Fabric - Temperatures Along Terminal Unit and Architectural Enclosure

23 Test 5165 Inch Woven Glass Fabric - Air Temperatures Architectural Enclosure

24 Test 5165 Inch Galvanized Steel - Temperatures Along Connector

25 Test 5165 Inch Galvanized Steel - Temperatures Along Terminal Unit and Architectural Enclosure

26 Test 5165 Inch Galvanized Steel - Air Temperatures Architectural Enclosure

27 Test 5166 Inch Galvanized Steel - Temperatures Along Connector

286 Inch Galvanized Steel - Temperatures Along Terminal Unit and Architectural Enclosure

29 Test 5166 Inch Galvanized Steel - Air Temperature Architectural Enclosure

30 Test 516 Comparison of Outlet Air Temperatures on Architectural Enclosures

31 Separation of 5 Inch Steel Connectors from Main Duct

32 Smoke Emitted at Architectural Enclosures

33 Comparison of Charring Inside the ONYP Terminal Units for the 5 and 6 Inch Diameter Steel Assemblies 


\section{REPORT OF FIRE TESTS}

ON

FLEXIBLE CONNECTORS IN HVAC SYSTEMS

\subsection{INTRODUCTION}

Compared to the buildings prior to 1950, the modern high-rise building with its central air conditioning system and high content of synthetic materials presents a greater hazard to life and to property in the event of fire. Current construction practices and code requirements must be continuously revised to cope with these factors.

One of the factors affecting the fire integrity of the building relates to the ability of the duct work to resist fire breaking into the duct and being carried through a fire resistive floor barrier via the duct system. An important component of the duct system is the flexible connector between the duct and the terminal unit on a floor above. The junction of the connector to the duct, the penetration of the connector through the fire resistive floor, and the materials used in the connector assembly can be sources of failure.

At the beginning of this program, a brief survey of the literature was made, which uncovered only a small amount of research information relating to the fire performance of flexible connectors and duct systems $[1,2,3]$.

This report summarizes the results of two tests designed to indicate the fire performance of flexible connectors as installed in a typical floorceiling construction. 
A pilot test (NBS Test 512) was laid out to examine the qualitative differences between the performance of flexible connectors of aluminum and of galvanized steel, to test the effectiveness of maintaining the integrity of the fire barrier, and to test a method of attaching the flexible connectors to a main duct.

Based on the results of the pilot test, an evaluation test (NBS Test 516) was laid out in which 2 non-metallic flexible connectors and 2 galvanized steel connectors were evaluated for their relative effectiveness in maintaining the fire barrier. Changes were made in the method of attaching the flexible connectors to the main duct and in the method of penetrating the fire barrier, compare the details on figures 1 and 12. The second test was also used to examine an assembly similar to the one used in the One New York Plaza building at the time of the fire in August 1970. [4]

At the present time there are no established fire test failure criteria for flexible connector assemblies. The criteria used to evaluate the flexible connector assemblies in this study was based on the temperature rise criterion for building construction assemblies in ASTM E 119. Thus, a temperature rise of $139^{\circ} \mathrm{C}\left(250^{\circ} \mathrm{F}\right)$, at the outlet of the architectural enclosure was taken as the termination point or effective fire endurance time. This criterion ensures that combustible materials such as drapes, papers, furnishings, that may be in contact with, or close to, the architectural enclosure will not be ignited for the period of the rating. 


\subsection{PILOT TEST}

\subsection{Description of Test (NBS Test 512)}

In the pilot test a 24 inch $\times 24$ inch square duct $10 \mathrm{ft}$ in length was hung from a ceiling closure constructed over the NBS floor furnace. In order to clear the duct over the furnace burners, it was necessary to build a hood-type closure which extended about 24 inches above the top of the furnace. See Figure 1 which shows the test layout and Figure 2 which shows a side view of the closure.

Three round flexible connectors ( 4 inch dia. aluminum, 4 inch dia. glavanized steel, and 6 inch dia. glavanized steel) were attached to the duct on the inside of the furnace, and through through the roof of the furnace to a simulated box type terminal unit. Each simulated terminal unit was in turn covered with a sheet metal architectural enclosure. The terminal units were of a size comparable to those used to provide heating and cooling capacity for an average size office or apartment module; and the architectural enclosures were sized to provide reasonable erection clearances around the terminal unit.

Figure 3 shows the two steel connectors attached to the main duct; Figure 4 shows the aluminum connector attached to the main duct; Figure 5 shows the steel connectors attached to the terminal units; Figure 6 shows the aluminum 
connector attached to the terminal unit; and Figure 7 shows the architectural enclosures in place.

The ducts were designed and manufactured by a local contractor in accordance with current design standards. [5]

\subsection{Furnace Closure}

The furnace closure consisted of a $2 \times 4$ (nominal) studs, 16 inch on center, forming the side walls and $2 \times 10$ (nominal) joists, 16 inch on center, forming the top. The inside of the closure was covered with two sheets of $5 / 8$ inch type $X$ gypsum board, which was protected with expanded metal lath and sprayed vermiculite plaster in order to provide a barrier with a minimum fire endurance of 2 hours.

The separations (gaps) between the flexible connectors and the hole through the furnace closure were packed with glass fiber, and were protected on the fire side with a steel flange plate. The steel flange plate was supplied by the manufacturer of the flexible connectors. Figure 8 shows the method of blocking the penetrations through the furnace closure.

\subsection{Flexible Connectors}

The flexible connectors consisted of a 4 inch diameter aluminum connector, a 4 inch diameter galvanized steel connector and a 6 inch diameter galvanized steel 
connector. This provided a comparison of two materials and a comparison of two sizes of steel connectors.

The flexible connectors were attached with steel friction strips to a standard flange plate attached to the duct; the details can be seen in Figures 3 and 4 .

The duct was covered with a rated 2 -inch thick glass fiber blanket. This was attached with a rated adhesive.

Inside the furnace the flexible connectors were covered with one inch fiber glass and a vinyl dust cover. Outside of the furnace enclosure the connectors were uncovered. This is in accordance with field procedures where the connector and duct may be insulated within a plenum or chase formed by the ceiling and the floor slab above it.

Both the duct and the portion of the flexible connectors that were inside the furnace were painted with a rated vapor barrier.

\subsection{Instrumentation}

The main duct was instrumented with four thermocouples to monitor the duct air temperature. Each flexible connector assembly was instrumented with 20 thermocouples. These were distributed as follows: 2 on the flexible 
connector under the insulation inside the furnace; 2 on the flexible connector outside of the furnace; 12 on the terminal unit; one in the airstream where the connector was attached to the terminal unit; 2 at the air inlet of the architectural enclosure; I in the air outlet; and 1 on top of the enclosure. The thermocouple layout is shown in Figure 9. These thermocouples were chromelalume1, type K, 24 gage.

The temperatures were recorded on both a paper tape temperature recorder and on a printing data logger. The paper tape data was transferred to a magnetic tape for processing with the NBS computer system.

In accordance with the requirements of NFPA $90 \mathrm{~A}^{[6]}$ the tests were run without air flow in the system.

\subsection{EVALUATION TEST}

\subsection{Description of Test (NBS Test 516)}

In this test four 18 inch diameter main ducts were hung from the furnace closure. One connector was attached to each duct. Figure 10 shows the test layout in the furnace.

Two non-metallic commercially available connectors, consisting of a 5 inch dia. glass fiber and a 5 inch dia. woven glass fiber 
fabric, were each attached from separate ducts to a simulated box type terminal unit and architectural enclosure similar to that used in the pilot test. Two metallic connectors, 5 inch dia. and 6 inch dia. galvanized steel, were each attached from separate ducts to a terminal unit similar to that used in the One New York Plaza Building at the time of the fire in August 1970. The architectural enclosures for these building terminal units (hereafter referred to as the ONYP terminal units) were sized to provide reasonable clearances and approximately the same volume as those for the box type units. The volume of the architectural enclosures for the ONYP units was $25 \mathrm{cu}$. $\mathrm{ft}$. while that for the box units was $24.75 \mathrm{cu}$. ft. Figure 11 shows the construction details for the fiber glass flexible connectors and Figure 12 shows the details for the steel flexible connectors.

The tests with the non-metallic flexible connectors and box type terminal units were similar to those in Test 512, except that round duct was ised in Test 516. The tests cannot be directly compared because of interaction effects that developed in Test 512 .

As in Test 512 there was no air flow in the assembly. 


\subsection{Furnace Closure}

The furnace enclosure was identical to that in the pilot test.

The penetrations through the furnace closure were altered from that used in the pilot test. The hole through the closure was only slightly larger than the connector and because of this tight clearance no glass fiber was packed into the space around the connector. On the fire side, the hole was blocked with a steel flange plate. The plate for the 6 inch diameter steel connector, which was supplied by the manufacturer of the flexible connectors, was made of stamped 19 gauge steel. The plates for the 5 inch diameter connectors were fabricated at NBS of welded $16 \mathrm{ga}$. steel. For the glass fiber duct, a suitable flange plate was unavailable at the time of the test so the hole around the duct was packed with glass fiber and was protected with vermiculate plaster on the fireside. Figure 13A shows the welded flange plate and Figure 13B shows the pressed steel flange plate. Figure $14 \mathrm{~A}$ and $14 \mathrm{~B}$ show the penetrations through the furnace closure for the steel and felted glass fiber connectors, respectively.

\subsection{Flexible Connectors}

The four connectors consisted of:

1. 5 inch inside diameter, 1 inch thick, felted glass fiber wrapped around a steel wire spiral and covered with a vinyl plastic cover. 
2. 5 inch inside diameter woven glass fiber, neoprene impregnated, wrapped around a wire spiral.

3. 5 inch inside diameter galvanized steel, average wall thickness $=.005$ in .

4. 6 inch inside diameter galvanized steel, average wall thickness $=.005$ in .

For this test the attachment of the steel connectors to the main ducts was changed to represent a common field type, as shown in Figures 12 and 15. Instead of using a flanged plate on the duct a small hole was cut in the duct and radial cuts were made from the edge of the hole out to the radius of the connector and the resultant strips were bent out to form ears. The connector was attached to the ears with a steel friction band. In addition to the bands, four self threading sheet metal screws were used to attach the connector to the bent out ears.

As in the pilot test, the main ducts were covered with a rated two inch thick aluminum foil-backed glass fiber blanket. This was attached with a rated adhesive and rated tape, see Figure 15.

Within the furnace both the woven glass fiber connector, and the steel connector were wrapped with a 1 inch thick glass fiber and covered with a vinyl plastic cover, which was supplied 
by the manufacturer of the flexible connectors. As in the pilot test, the main ducts and the connectors were painted with a rated vapor barrier. See Figures $14 \mathrm{~A}$ and $14 \mathrm{~B}$.

\subsection{Instrumentation}

\subsubsection{Glass Fiber Connectors}

The glass fiber flexible connectors were each instrumented with 19 thermocouples distributed in the following way: 2 inside the main duct*, 4 on the surface of the main duct, 2 on the duct hangars, 2 on the connector under the vinyl cover for the felted connector inside the furnace, 2 on the connector outside of the furnace, 1 at the inlet to the terminal unit, 2 at the outlet of the terminal unit, 2 in the inlet of the architectural enclosure and 2 in the outlet of the architectural enclosure. The thermocouple details for the glass fiber connectors assemblies are shown in Figure 11. The thermocouples were 24 gage, chromel alumel (type $\mathrm{K}$ ).

\subsubsection{Stee1 Connectors}

For the steel connectors, 21 thermocouple channels were used. The only differences in arrangement were on the ONYP terminal unit where 3 thermocouples were placed on the discharge compared with 2 on the box units and an additional thermo-

* Thermocouples $14 \mathrm{~A}$ and $14 \mathrm{~B}$, and $15 \mathrm{~A}$ and $15 \mathrm{~B}$ were connected in parallel. 
couple was placed on the cold side inlet valve of the terminal unit. The thermocouple details for the steel connectors assemblies are shown in Figure 16.

\subsection{TEST RESULTS}

\subsection{Pilot Test (NBS Test 512)}

Since all the connectors were connected to the same main duct, after the failure of the first connector, cross current drafts were introduced which prevented the collection of meaningful temperature data. For this reason no temperature data for test 512 are included in this report.

These interaction effects indicate that in a system in a "shut down condition" smoke and hot gases can easily enter and be distributed throughout the system.

\subsubsection{General Observations}

After 6 minutes of test the aluminum connector melted. The steel flexible connectors remained intact until they separated from the duct at 89 minutes.

\subsection{Evaluation Test (NBS Test 516)}

In this test employing independent ducts, interaction effects resulting from the failure of any one connector were eliminated. The results for the glass fiber connectors and the steel connectors will be discussed separately. 


\subsubsection{Temperature Observations}

\subsubsection{Furnace Temperatures}

The furnace temperatures were measured with 12 shielded thermocouples which were in accordance with the requirement of ASTM E 119. The furnace temperature followed the standard curve of ASTM E 119 closely and no correction was needed. The average furnace temperatures are shown in Figure 17.

\subsubsection{Connector Assembly Temperatures}

The temperatures for the assemblies are shown in Figures 18 to 30 on four sets of three graphs, and a summary graph. The first graph of each set shows the temperatures from the main duct to the inlet of the terminal units. The second graph shows the temperatures from the inlet of the terminal unit to the outlet of the architectural enclosure, and the third graph shows only the inlet and outlet temperatures at the architectural enclosure. Figure 30 compares the outlet temperatures of all four architectural enclosures.

\subsubsection{Glass Fiber Connectors}

A comparison of the temperature records for the felted glass fiber assembly (Figures 18, 19, and 20) with those for the woven glass fiber fabric assembly (Figures 21, 22 , and 23) suggests that there was no great difference in the temperature performance of the two non-metallic 
connector assemblies. The visual observations during and after the test indicate that the woven glass fiber fabric assembly was marginally superior.

During the test both glass fiber connectors had melted inside the furnace by about 15 minutes of test time. The woven fabric connector however maintained some structure until about 23 minutes of test time. Outside of the furnace the woven fabric connector maintained enough structure to contain the hot gases for the full period of the test, while the felted glass fiber connector melted above the furnace closure and it was necessary to block off this penetration at 41 minutes of test time. Before blocking off the penetration of the felted fiber glass connector, the air inlet temperatures at the terminal unit were similar for both of the non-metallic connectors.

It should be emphasized that in this test there was, in general, very little air movement from the furnace through the opening in the connectors. This is because the NBS test furnace, like most floor test furnaces, operates under neutral to slightly negative pressure. In an actual fire situation, the hot gases would probably be under slight positive pressure and so air movements through openings in the connectors and around the connector penetrations would be relatively more serious than occurred in this test when the non-metallic connectors failed. 


\subsubsection{Steel Connector Temperatures}

Comparing the temperatures of the two steel connector assemblies, in Figures 25 to 28, it is seen that from about 30 minutes to the end of the test the inlet temperatures to the terminal unit for the 5 inch connector are about $675^{\circ} \mathrm{C}$ while those for the 6 inch connector are about $500^{\circ} \mathrm{C}$. During the test it was observed at 32 minutes that the 5 inch connector was separating from its duct. However, the abrupt rise in temperature at the outlet of the architectural enclosure would indicate that the separation probably occurred at about 20 to 25 minutes. This separation which is shown in Figure 31 allowed hot furnace gases to enter this assembly and so produce the higher observed temperatures in the 5 inch connector assembly.

\subsubsection{Comparison Data}

In Figure 30 the outlet temperatures above the four architectural enclosures are compared. The rise in temperature, at the outlet of the 6 inch galvanized steel assembly, at the end of one hour is below the allowable temperature rise of $139^{\circ} \mathrm{C}$ which is usually taken to represent the temperature transmission limit. The 5 inch assembly exceeded the $139^{\circ} \mathrm{C}$ rise because the connection opened up, showing that the connector assembly was governed by its connection. The pilot test (NBS test 512) showed that a flanged connection could remain intact for this period. 


\subsection{DISCUSSION AND SUMMARY OF RESULTS}

5.1 Temperature and Fire Endurance

The two tests studied the effects of fire breaking into an HVAC assembly through the flexible connectors. Since the flexible connector penetrates a fire-rated floor assembly, its construction should provide equivalent protection against fire transmission. The criteria of failure used in these tests are based on the ASTM E 119 (7) criterion for temperature transmission - the rise in temperature should not exceed $139^{\circ} \mathrm{C}$ nor should there be any flame transmission. The temperature rise criterion was applied to the temperature on top of the architectural enclosure. The criterion was applied at one hour, consistent with a fire duration based on the expected fire load in an office building.

The tests showed that the criterion could be met if the fire did not enter the flexible connector, the main duct, or any part of the HVAC system. Since a connector must maintain its integrity against fire penetration, the method of attaching the connector to a main duct and the fire stopping around the penetrations through a fire barrier must also be able to withstand the temperature for the required fire exposure period.

The pilot test showed that a flanged fitting to the main duct kept the steel connector attached. In the 
second test, using a field type of attachment one steel connector held and one separated from the main duct.

The behavior of the 5 inch galvanized connector in the second test, showed that if the method of attaching the connector to the main duct allows the joint to open up, the transmitted temperatures will be similar to those of a non-metallic duct or of a low melting point metal duct. The steel connector when properly attached prevented the fire from entering the system and heating the architectural enclosure above an allowable limit.

It is emphasized that the performance reported assumes only a very low to zero flow in the HVAC system, consistent with the supply air in the fire area being shut down in accordance with NFPA standard 90A.

\subsection{Smoke and Toxic Gases}

During the early part of the evaluation test, moderately dense and irritating smoke came out of all four assemblies. As the test progressed the amount of smoke decreased. A qualitative comparison is shown in Figure 32.

In the non-metallic assemblies the smoke and irritating gases probably came from the resin and plastic in the glass fiber, while in the steel assemblies it may have 
come from the rubber fittings and the impregnated glass fiber air filter in the ONYP terminal units. A comparison of the charring of the filters in the terminal ONYP units is shown in Figure 32 .

Though this investigative program was primarily concerned with the fire resistance of flexible connector assemblies, the observed smoke development during the test indicate the need for additional research to develop criteria for measuring and limiting the amount of smoke generated by materials in these assemblies.

\subsection{Comparison of Square and Round Ducts}

The two tests provided an opportunity to compare, in a subjective way, the performance of square and round ducts.

During the pilot test with square ducts, the glass fiber wrapping separated within a few minutes allowing the furnace heat to impinge directly onto the full length of the duct. As the test progressed the sides of the duct tended to buckle, reducing the height of the duct, and thus reduce the bending stiffness* of the duct faster than the reduction in strength due to heating alone.

* Bending stiffness is proportional to the square of the depth. 
With the circular ducts, the insulation remained in place for approximately 15 minutes, protecting the duct from the direct furnace heat for this period. As the test progressed the ducts tended to flatten in a horizontal direction, that is, the vertical sides moved towards each other, decreasing the horizontal diameter of the duct. This type of deformation would tend to keep the bending stiffness proportional to the heated strength of the duct metal.

The tests suggest that a round duct may maintain its structural integrity better than a square duct under a fire exposure. It should be noted however that the test did not include any comparison of joint strength or span lengths both of which affect performance. The relative strengths of round and square ducts and the factors affecting the performance of round ducts can only be determined by further tests.

\subsection{Performance Considerations}

If the following conditions are met:

Element or Assembly

flexible connectors

joints
Required Performance

do not melt

do not pyrolize

remain intact

remain tight 
Then, the flexible connector assembly will keep the fire out of a compartment, and the temperatures in the compartment may remain low enough to prevent ignition of combustibles in the room above.

For life safety an additional requirement is that the terminal unit does not contain materials that will degrade under heat and give off excessive smoke and noxious gases. Possible sources for these include binder and impregnates in the air filter, rubber and plastic inserts and baffles (see paragraph "5.2 Smoke and Toxic Gases").

Though these requirements may seem self evident they are more restrictive than those required under NFPA 90A [6].

\subsection{ACKNOWLEDGEMENT}

This research was supported in part by a grant from the American Iron and Steel Institute. 
Summary of Observation Made During Pilot Test (NBS Test 512)

Test Time

Hrs: Min

$00: 02$

$00: 05$

$00: 06$

$00: 14$

$00: 21$

$00: 35$

$00: 43$

$00: 50$

$00: 54$

$01: 05$

$01: 29$

\section{Observation}

The insulation on the bottom of the main duct has separated from the duct and is hanging down from one edge.

Smoke coming out of architectural enclosures. The aluminum connector has melted.

Insulation on the main duct is essentially destroyed at this time. Insulation on the 4 and 6 inch galvanized steel connectors is still partially intact. The insulation is melting in place rather than falling off into the furnace.

The 4 inch steel connector is a dark color while the 6 inch steel connector is glowing a dull red. Main duct starting to deform in an accordian manner .

Some smoke still coming out of the architectural enclosure of the 6 inch steel connector assembly. Both steel connectors are glowing red. Flange connections holding up quite well. T'wo technicians checking the 4 inch galvanized duct for obstruction. No obstructions found. Six inch connector has separated from main duct. 


\section{APPENDIX B}

Summary of Observations Made During Evaluation Test (NBS Test 516)

$\frac{\text { Test Time }}{\text { Hrs:Min }}$

$00: 02$

$00: 03$

$00: 05$

$00: 07$

\section{Observations}

The insulation has come off both the 5 inch and

6 inch steel flexible connectors. (Note that

this was applied by NBS prior to test).

Air is coming out of all four architectural

enclosures. (This was checked with a piece of

thin aluminum foil hung from a rod which indicates

that there is air movement). There is also moderately

dense smoke coming out.

The insulation around the main ducts appears to be smoking and flaming.

Smoke is still coming out of each one of the

architectural enclosures. The smoke seems to be a

little denser from the two glass fiber connectors

assemblies. Smoke at the top of the furnace is

acrid and it is difficult to stay up there for more

than a few minutes, and it has partially obscured

vision across the top of the furnace. See Figure 31

showing the smoke conditions at the top of the

furnace.

The insulation is staying in place even though its deteriorating from the heat. The insulation on the 
main ducts has split. The splits are circumferential and are about $3^{\prime}$ long.

The insulation is starting to fall off the main duct, it is falling off in pieces and appears to be deteriorated at this time. The smoke is still coming out of the architectural enclosures.

$00: 19$ The neoprene fabric connectors continues to show some structure.

$00: 20$

The remnants of the glass fiber insulation around the main ducts continue to fall into the furnace. The parts of the main duct that are visible show some localized buckling. The glass fiber is dripping and melting into the furnace.

$00: 23$

The neoprene impregnated woven fiber glass flexible connector at the south east corner has fallen in.

$00: 26$ Referring to the two steel connectors at the center of the furnace, the main ducts appear to be collapsing and pulling away from the connectors. Both these ducts seem to be collapsing in sort of a vertical plane and pulling away from the connectors and there seems to be some deteriorating at the junction point.

$00: 29$ The architectural enclosure attached to the glass fabric connector has no air coming out of the top. At the assembly with the glass fiber connector there is air coming out of the architectural enclosure. 
The 5 inch steel connector has separated from its connection at the main duct, though it is still hanging in place. See Figure 33.

$00: 35$ The architectural enclosure connected to the woven glass fiber connector now has air flowing out of it again. The main ducts are starting to deflect significantly. It would say that they have all deflected about 5 or 6 inches. On the top of the enclosure where the standard glass fiber duct connector is located it is necessary to put a cap over the hole where the flexible connector comes through. Too much heat is coming through and it may ignite the closure.

$00: 53$ The smoke has abated but there is still smoke coming out through the two architectural enclosures that are attached to the steel connectors, visibility is fair. The furnace closure is charring and smoking a little. The 6 inch galvanized steel flexible connector is still in place.

The roof closure is starting to burn through; the crackling sounds have become quite severe. The 6 inch galvanized steel flexible connector is still intact. Gas off. Fire was breaking through the furnace closure. End of test. 


\section{BIBLIOGRAPHY}

1. J. A. Wilson and J. J. Capron

"The Fire Hazard of Fibrous Glass Ducts - An Evaluation,"

Fire Technology, Vol. 2, No. 1, Feb. 1966, pp. 24-36,

National Fire Protection Association, Boston, Massachusetts.

2. A. F. Roberts, G. Clough, and J. R. Blackwell

"A Model Duct for Mines Research," Safety in Mines Research Establishment Research Report No. 243, Dec. 1966, Sheffield, England.

3. A. F. Roberts and G. Clough

"The Propagation of Fire in Passages Lined with Flammable Material," Combustion and Flame, Vol. II, No. 5, October 1967, pp. 365-376, Butterworths, London, England.

4. W. Robert Powers

"Report of Fire at One New York Plaza, New York, N.Y.", The New York Board of Fire Underwriters, Bureau of Fire Prevention and Public Relations, 1970, New York, N.Y.

\section{Anonymous}

"Low Velocity Duct Construction Standards" - 4th Edition, Sheet Metal and Air Conditioning Contractors National Association, Inc. (SMACNA), 1969, Washington, D.C. 
6. Anonymous

"Installations of Air Conditioning and Ventilation Systems 1971," NFPA 90A, National Fire Protection Association International, Boston, Massachusetts.

7. Anonymous

"Standard Methods of Fire Tests of Building Construction and Materials," Designation E 119, American Society for Testing and Materials, Philadelphia, Pennsylvania, 1971. 


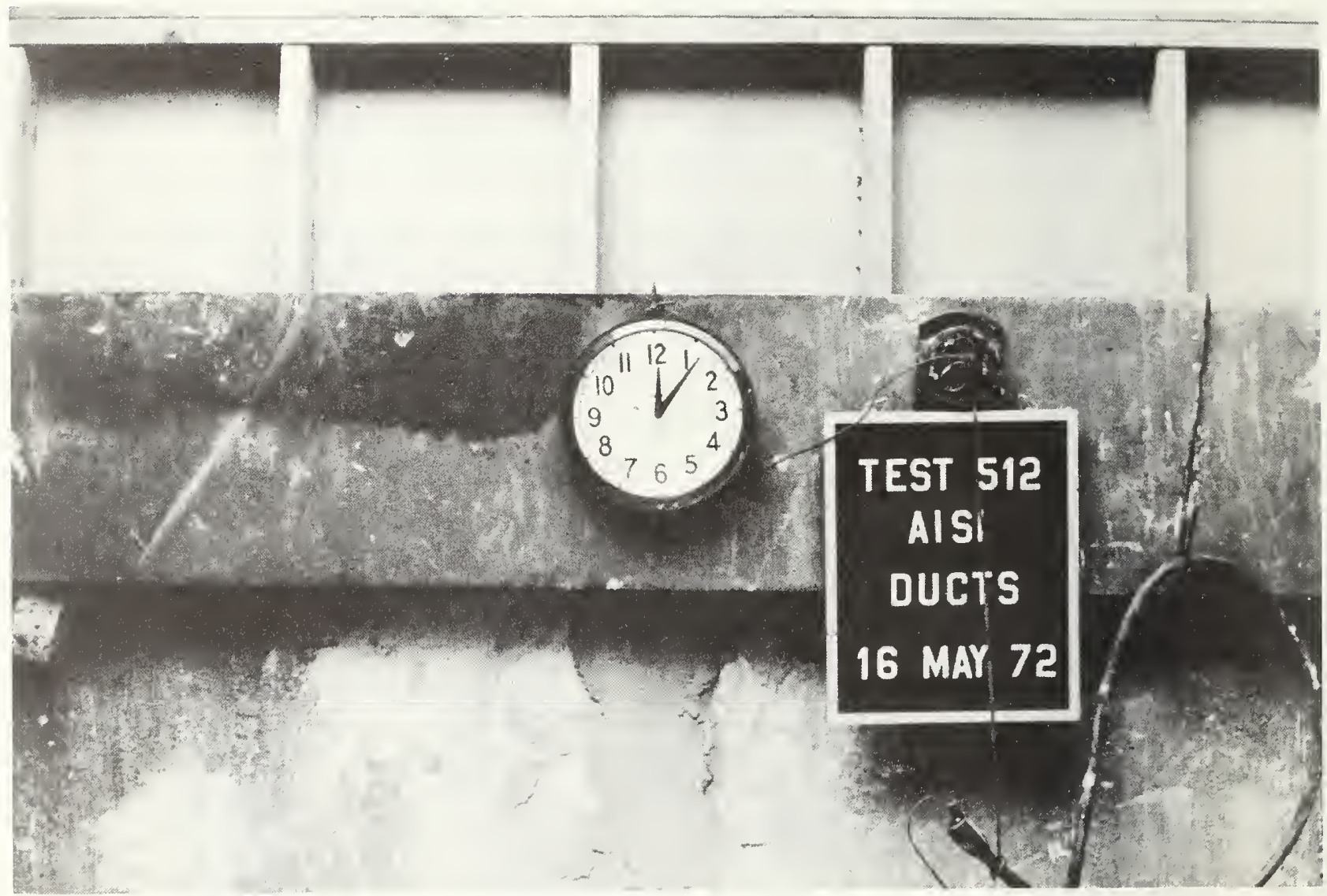

Figure 2 - Test 512- Side of Raised Furnace Closure 


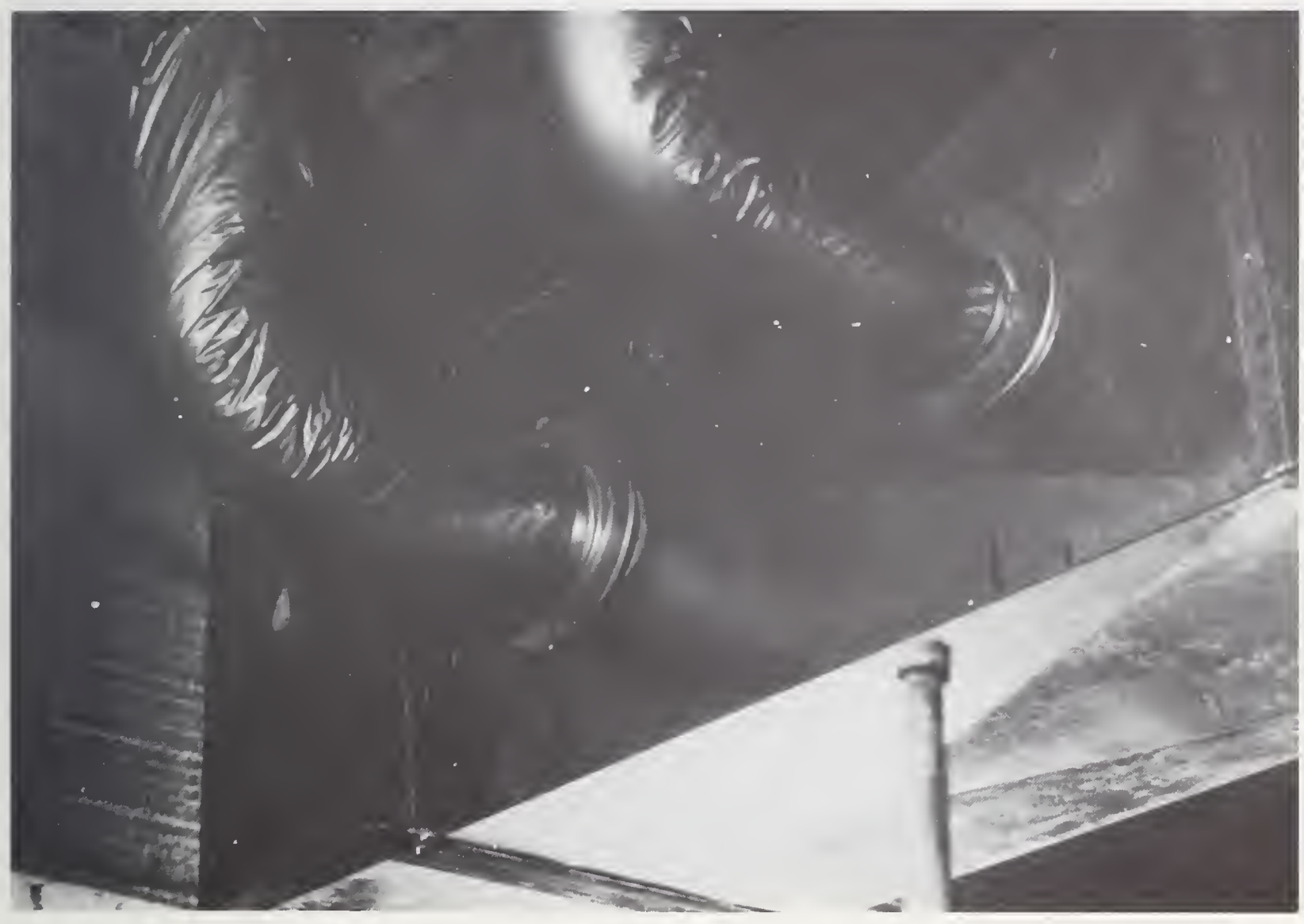

Figure 3 - View of Steel Connectors Showing the Vinyl Covering and the Method of Attaching to the nuct. 


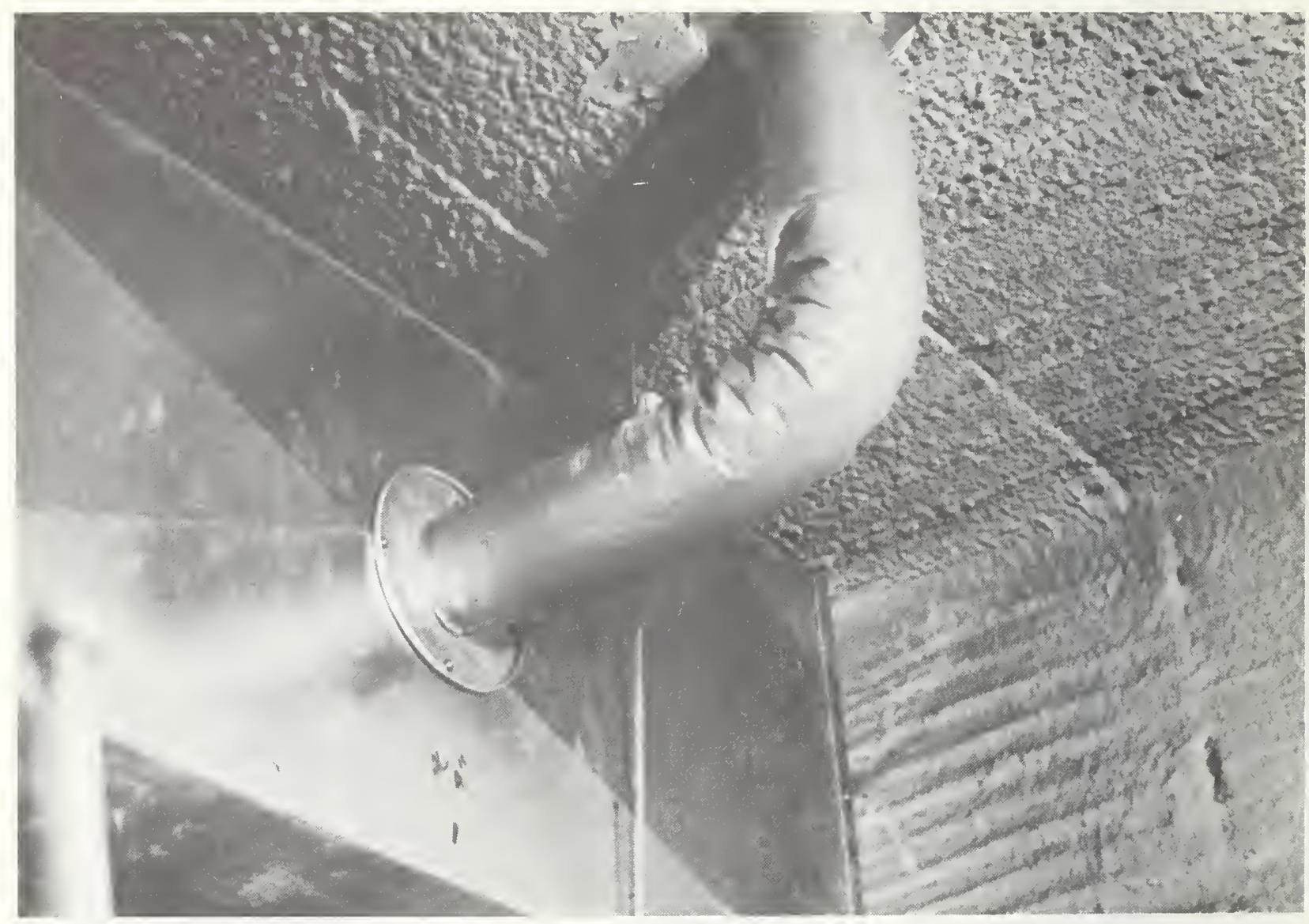

Figure 4 - Test 512 - View of Aluminum Connector Attached to the Main Duct 


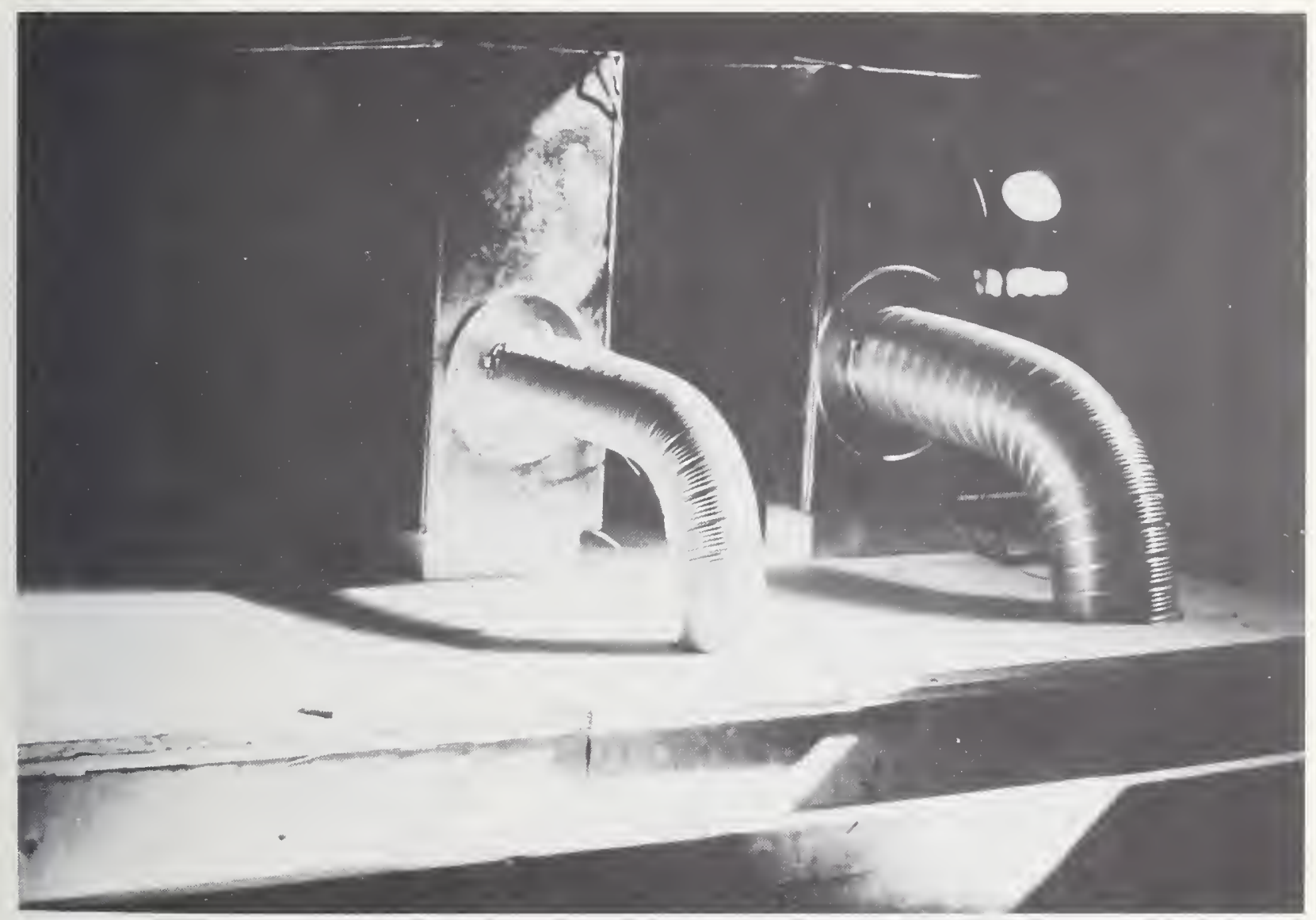

Figure 5 - Test 512 - View of Steel Flexible Connectors at Terminal Unit 


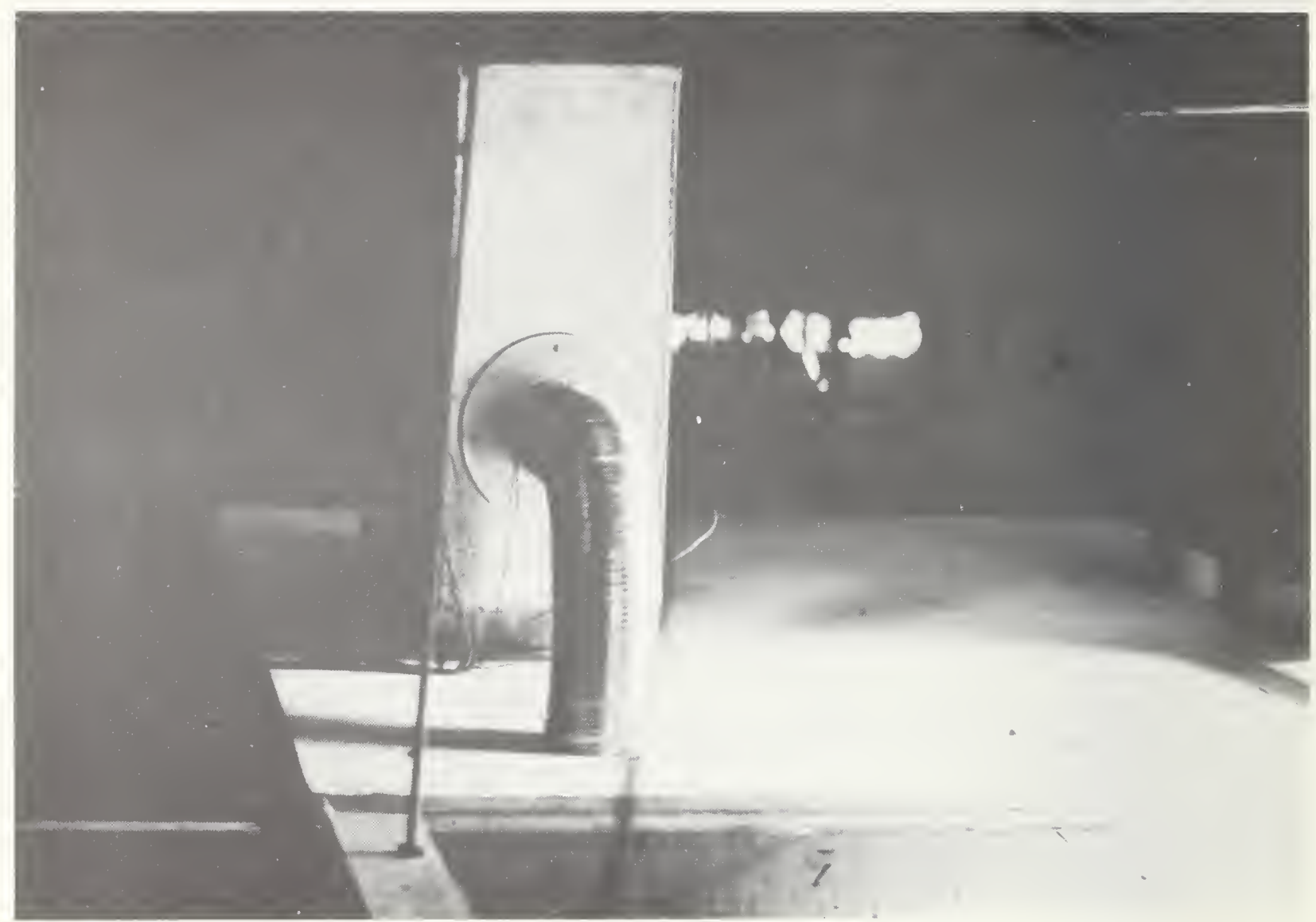

Figure 6 - Test 512 - View of Aluminum Flexible Connector at Terminal Unit 


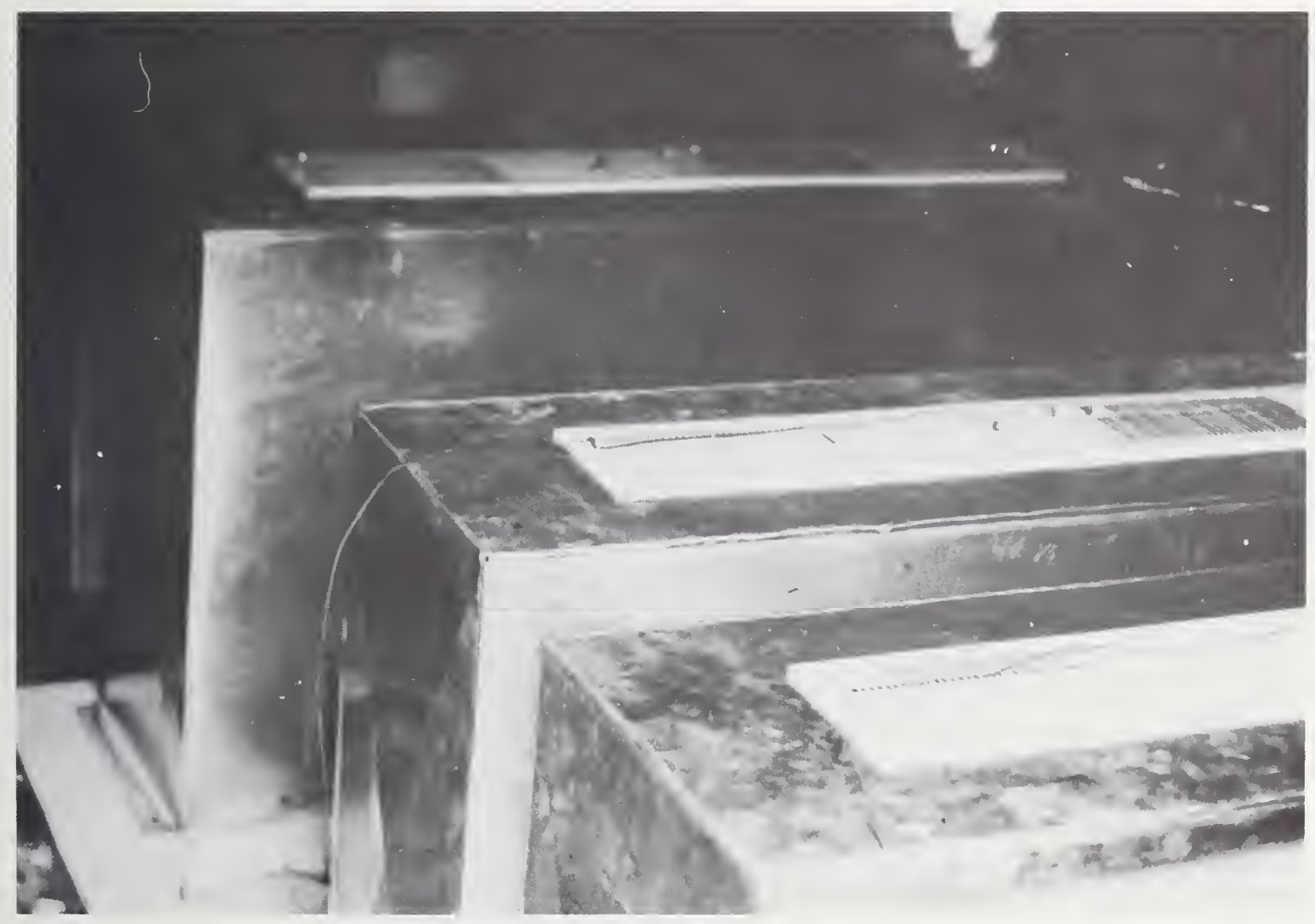

Figure 7 - Test 512 - Architectural Enclosure in Place 




Figure 8 - Test 512 - Aluminum Flexible Connector. (Note method of blocking penetrations through closure) 

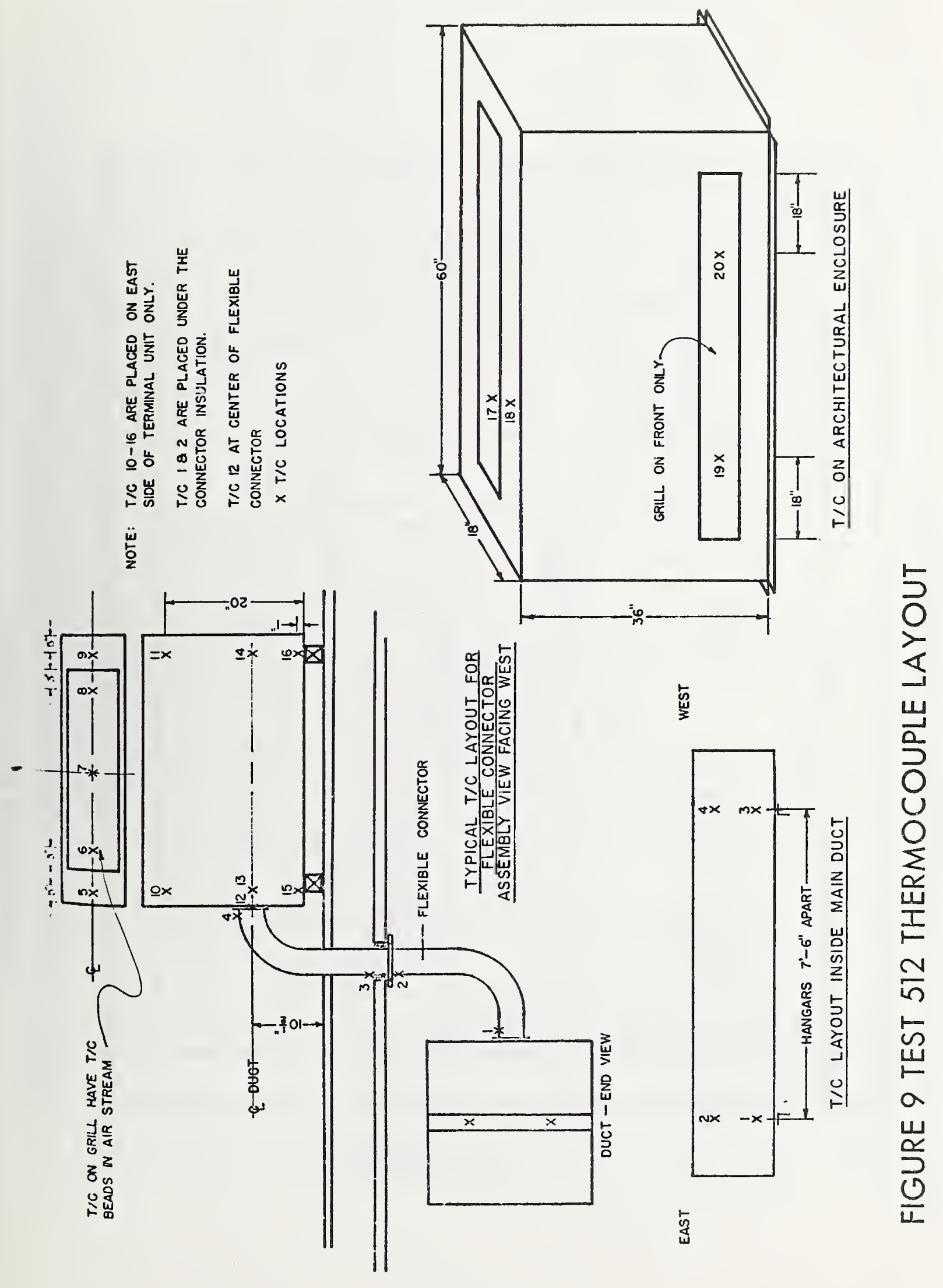


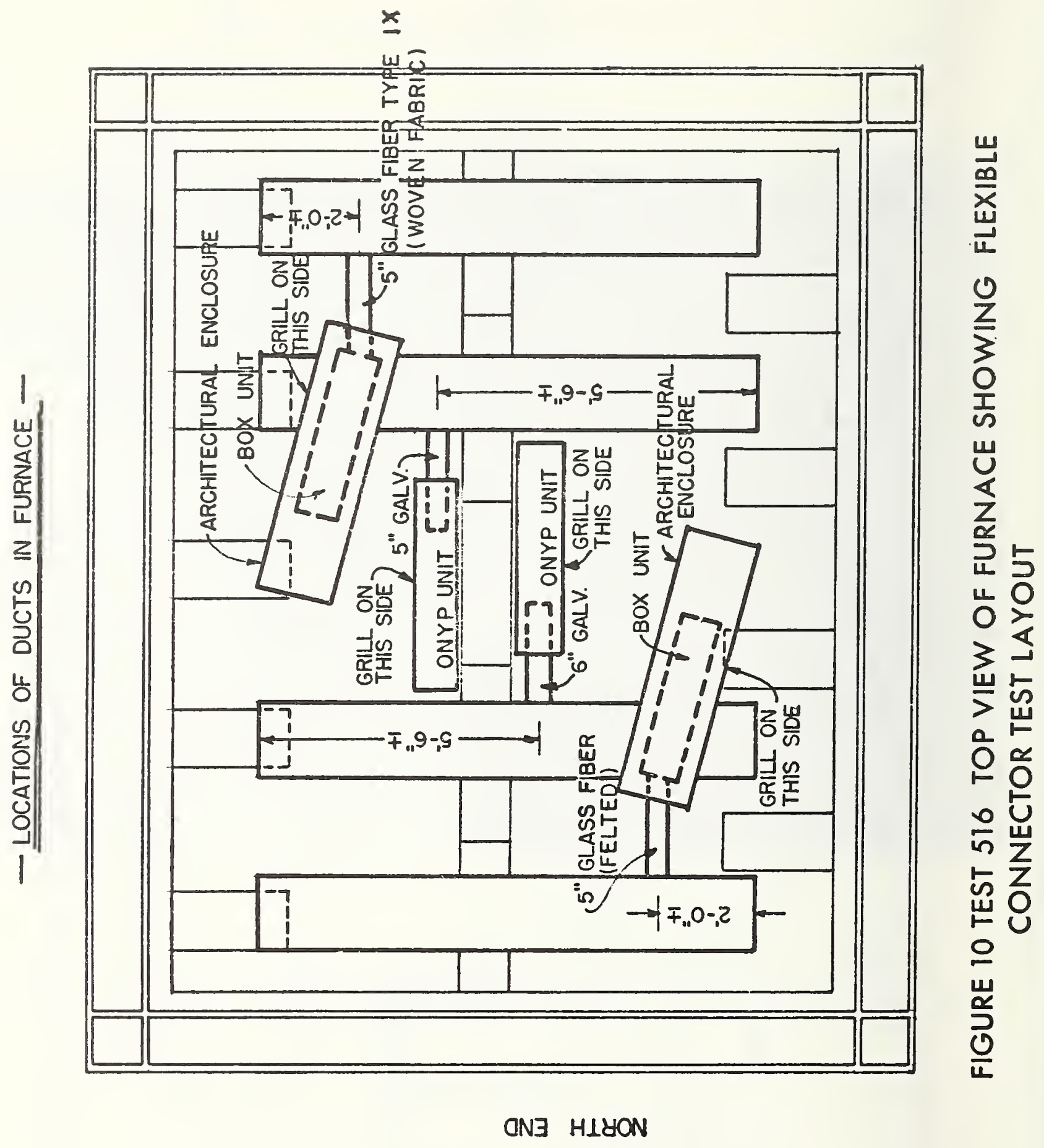




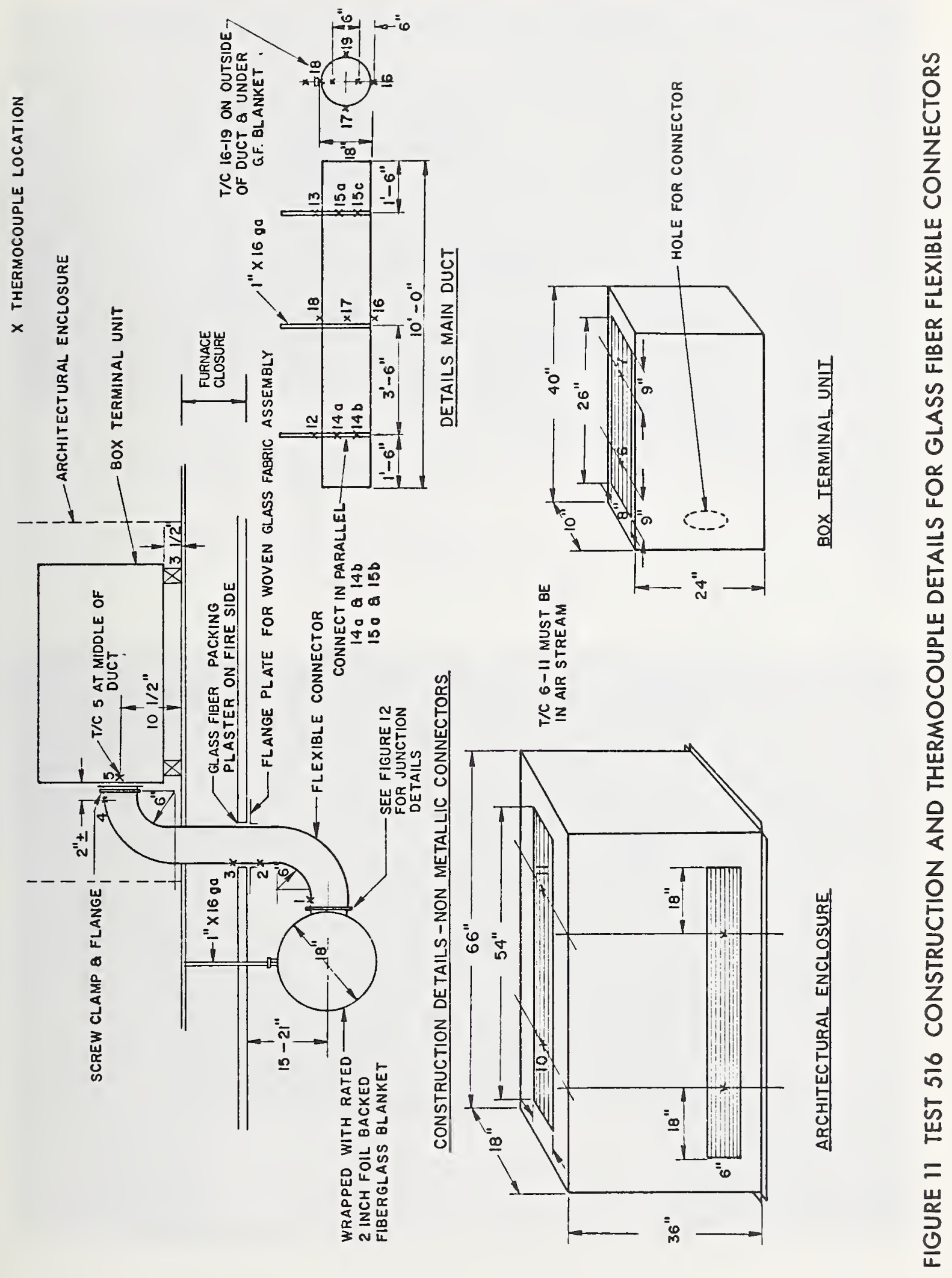








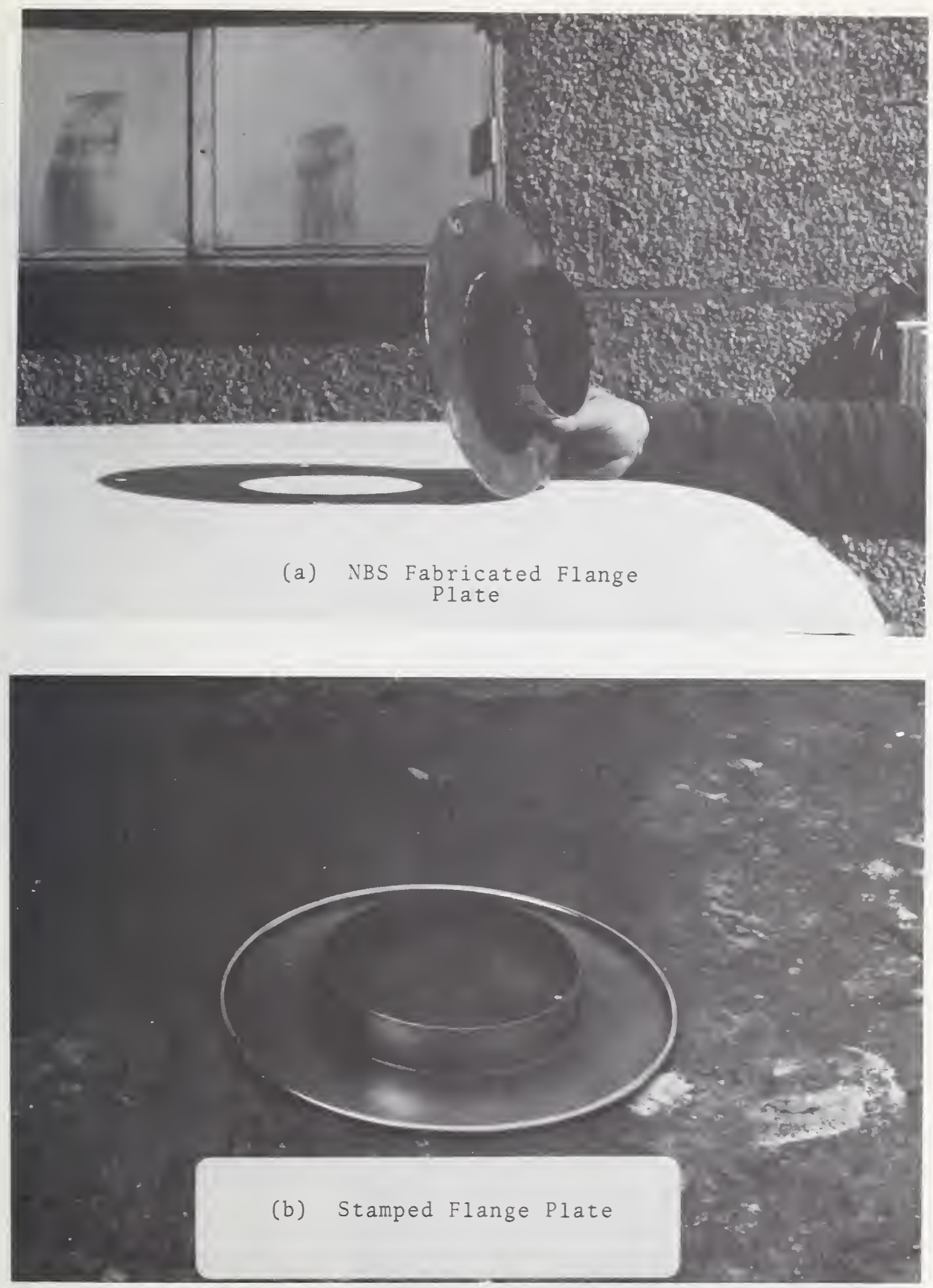

Figure 13 - Flange Plates 

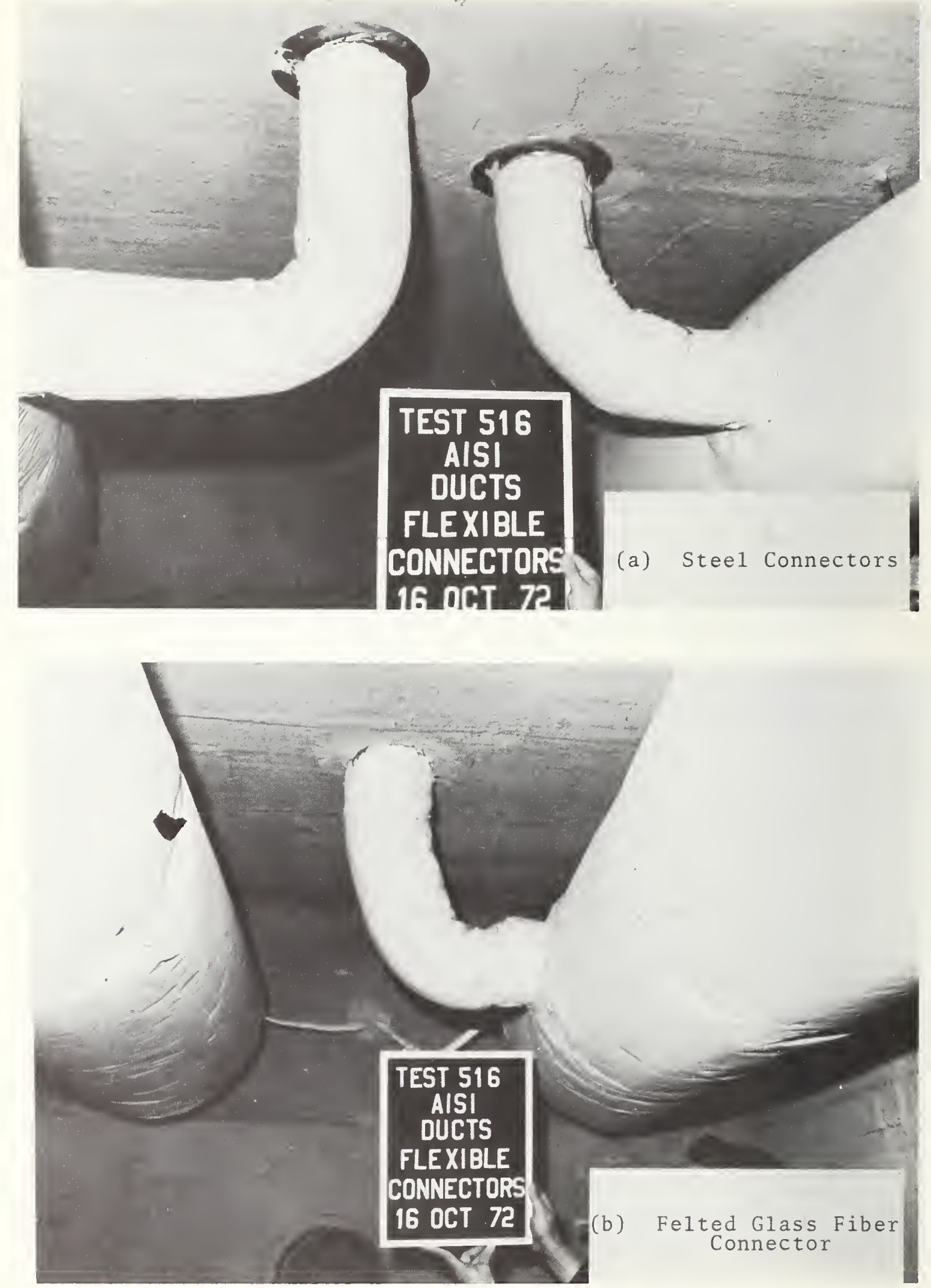

Figure 14 - Penetrations through Closure 


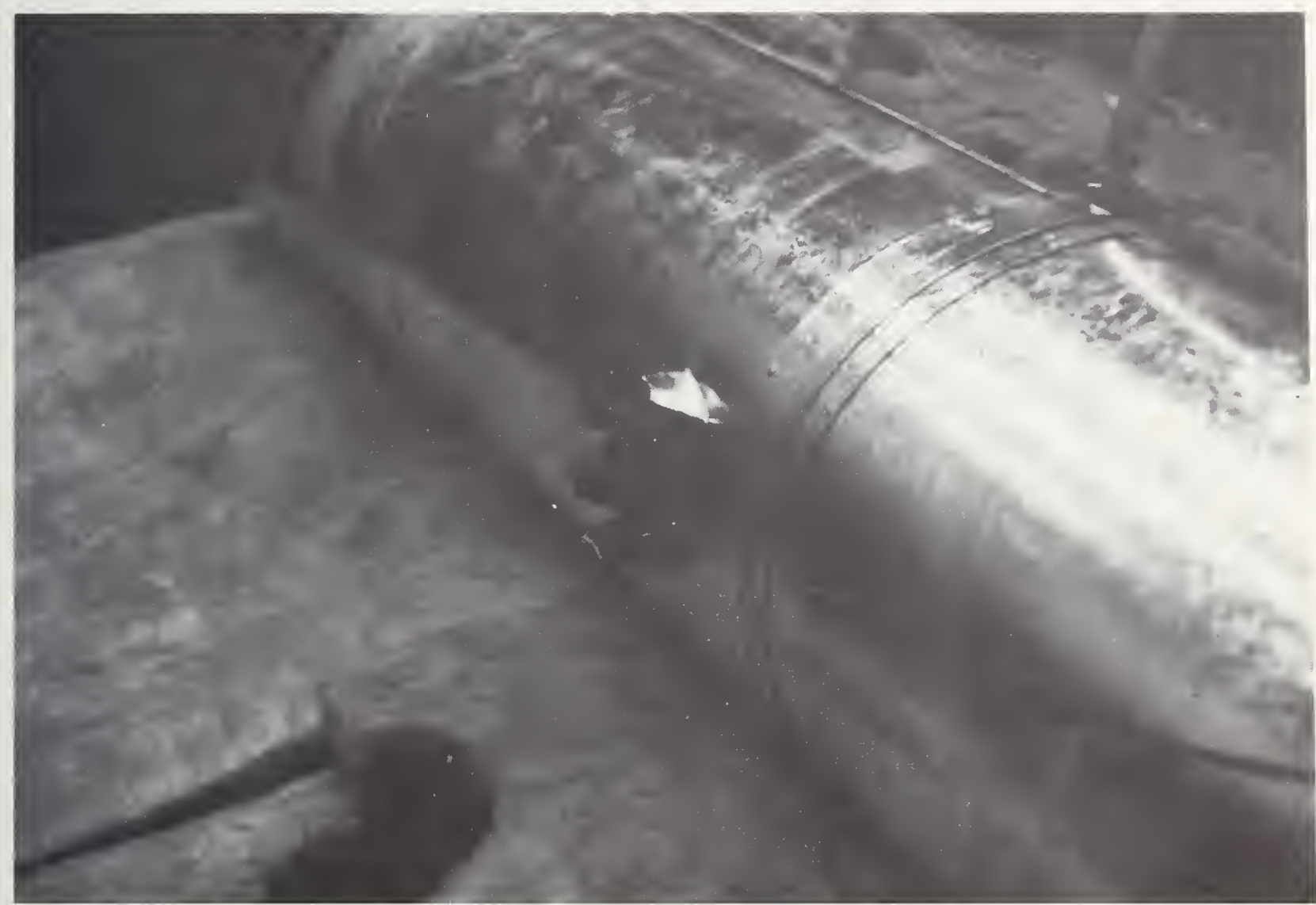

Figure 15 - Typical Duct Showing Glass Fiber Blanket and Connector Junction Point 







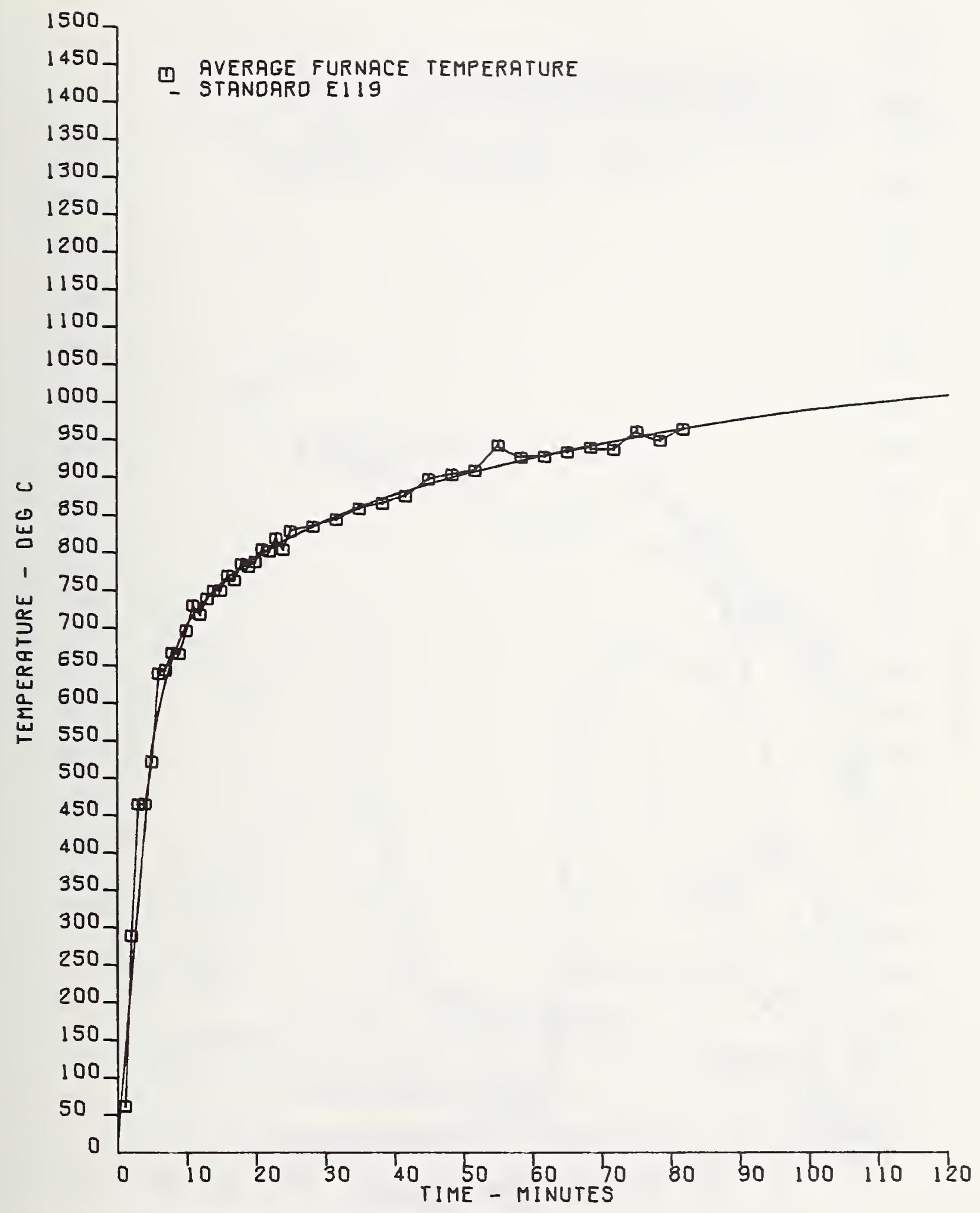

FIG. 17 TEST 516 FURNACE TEMPERATURES 


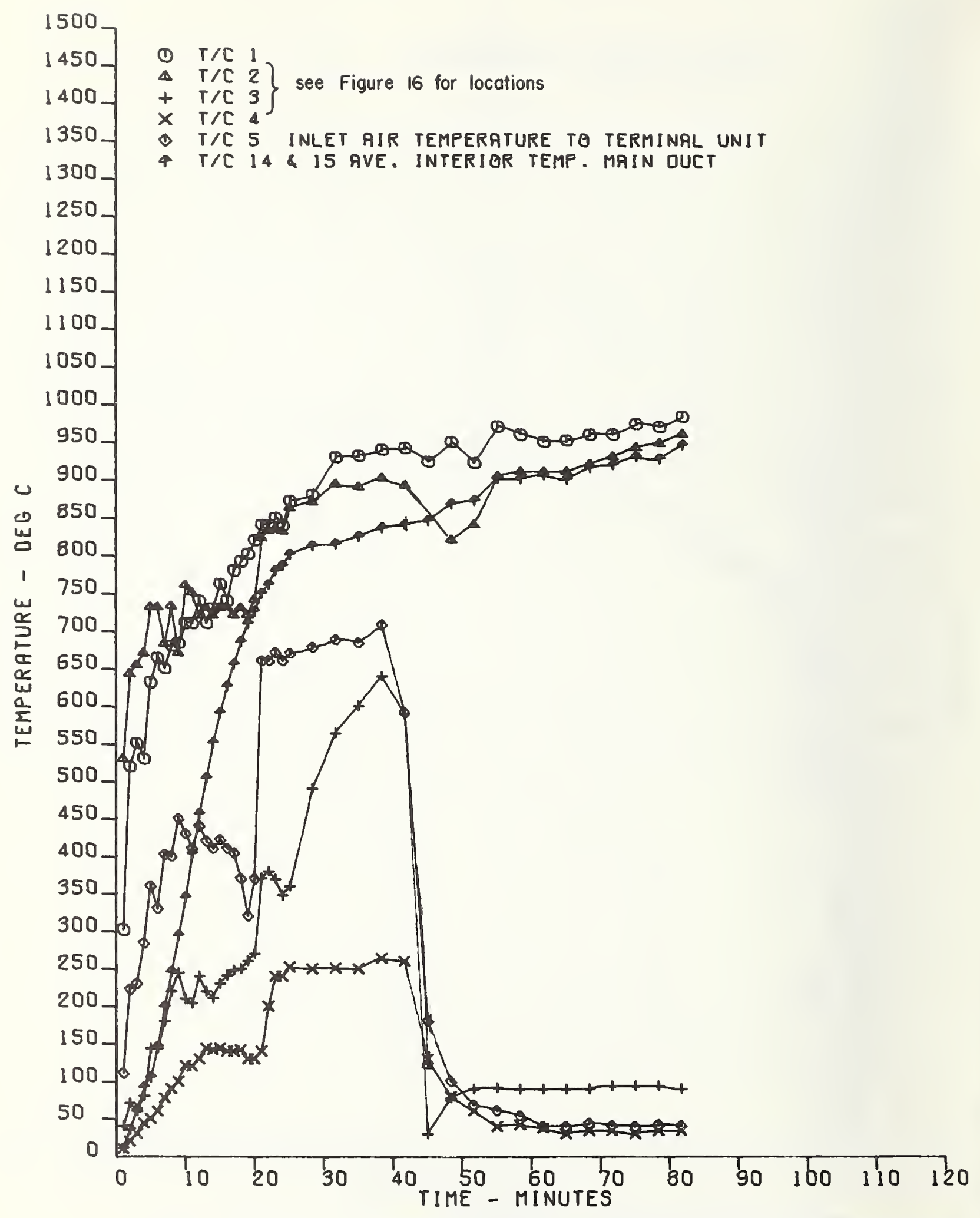

FIG. 18 TEST 5165 INCH GLASS FIBER - TEMPERATURES ALONG CONNECTOR 


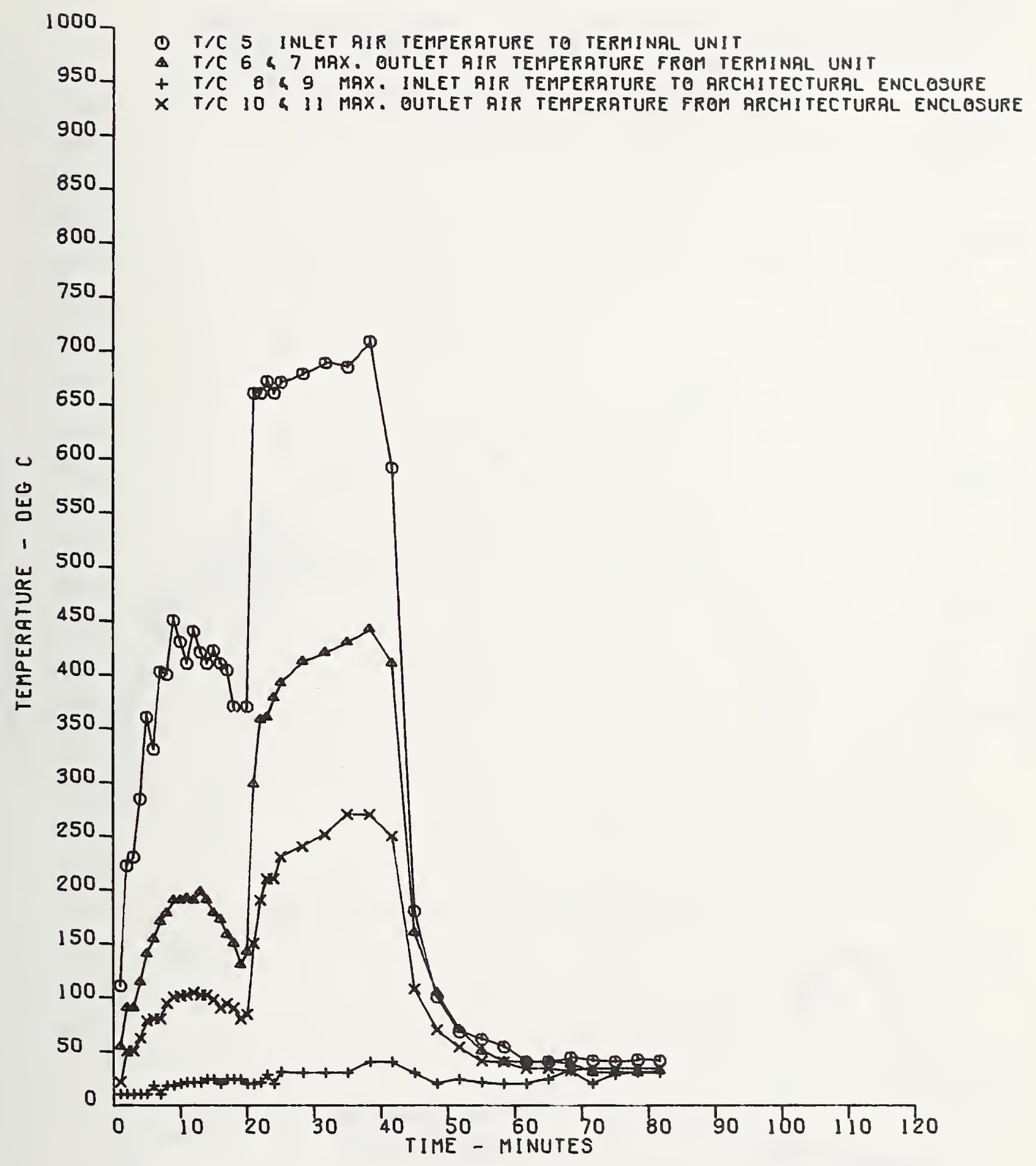

FIG. 19 TEST 5165 INCH GLASS FIBER - TEMPERATURES ALONG TERMINAL UNIT AND ARCHITECTURAL ENCLOSURE 


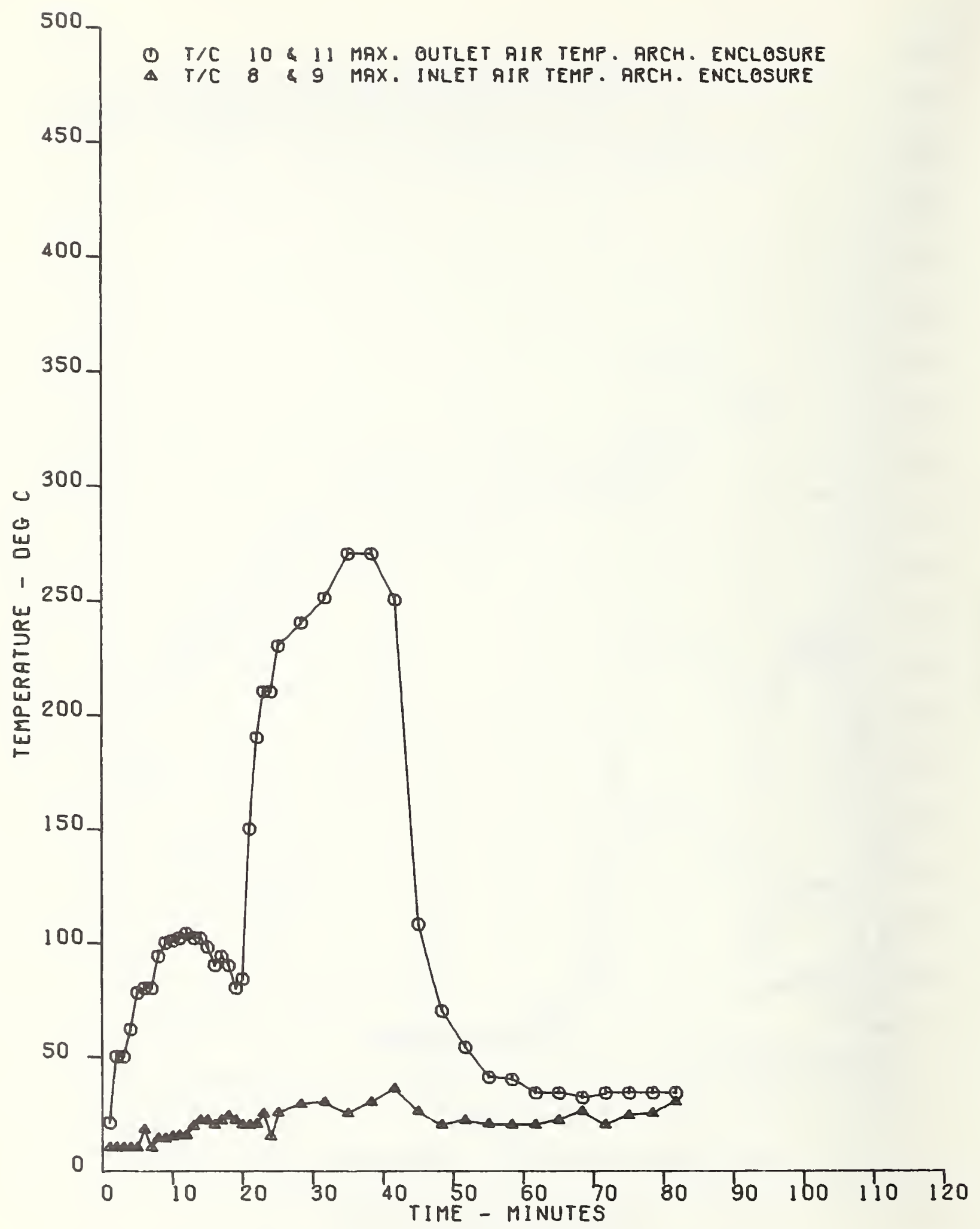

FIG. 20 TEST 5165 INCH GLASS FIBER - AIR TEMPERATURES ARCHITECTURAL ENCLOSURE 


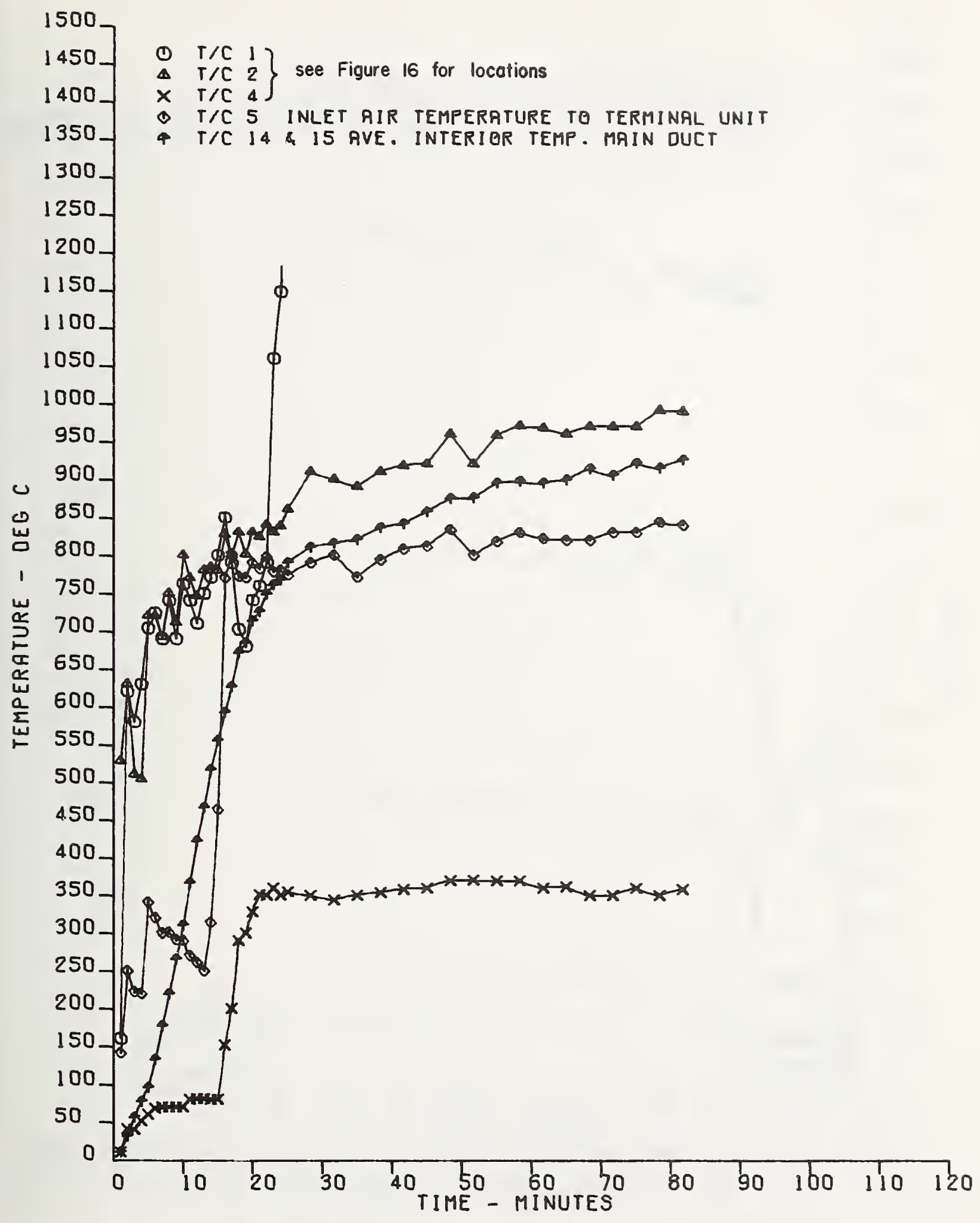

FIG. 21 TEST 5165 INCH WOVEN GLASS FABRIC * TEMPERATURES ALONG CONNECTOR 


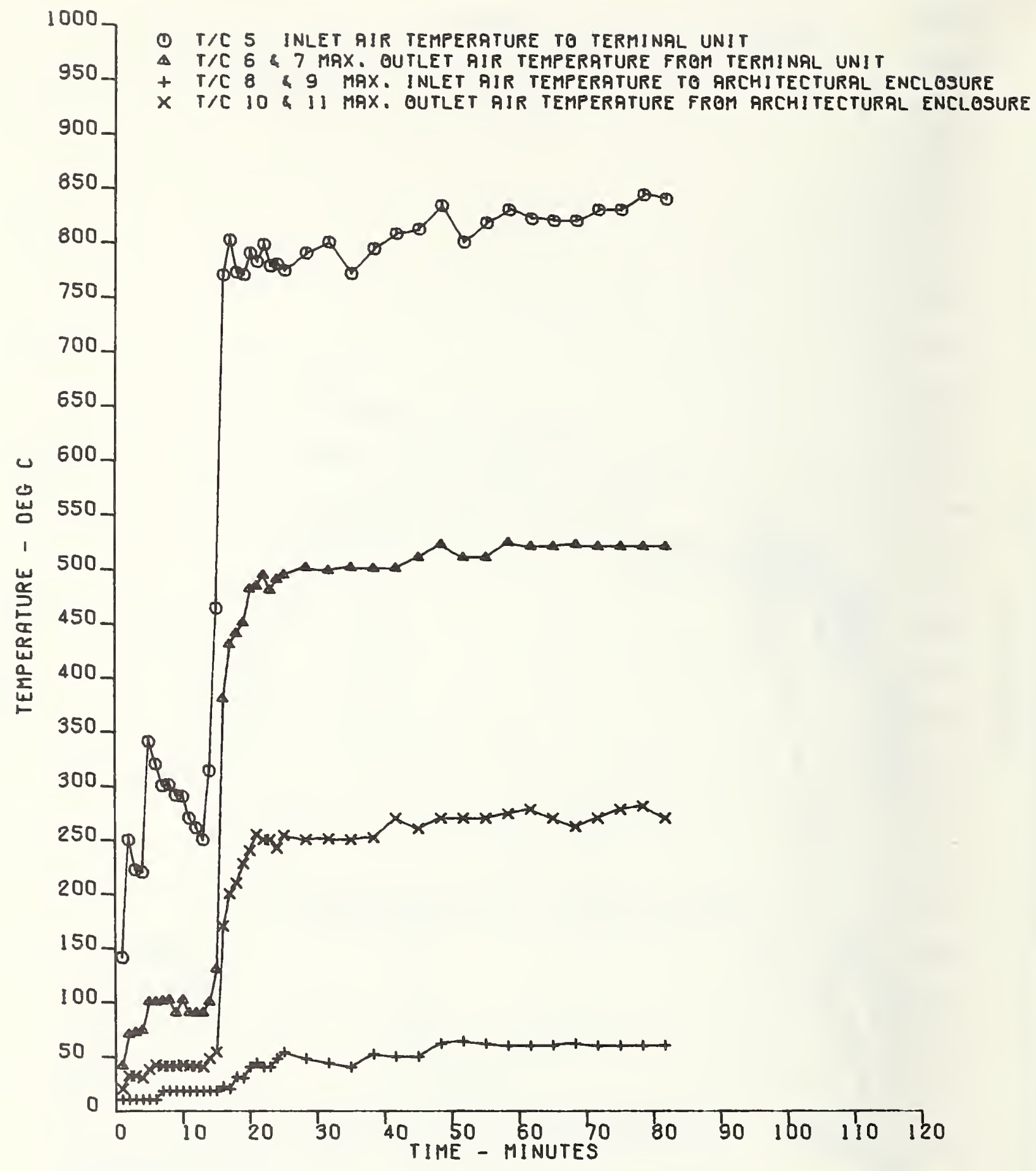

FIG. 22 TEST 5165 INCH WOVEN GLASS FABRIC - TEMPERATURES ALONG TERMINAL UNIT AND ARCHITECTURAL ENCLOSURE 


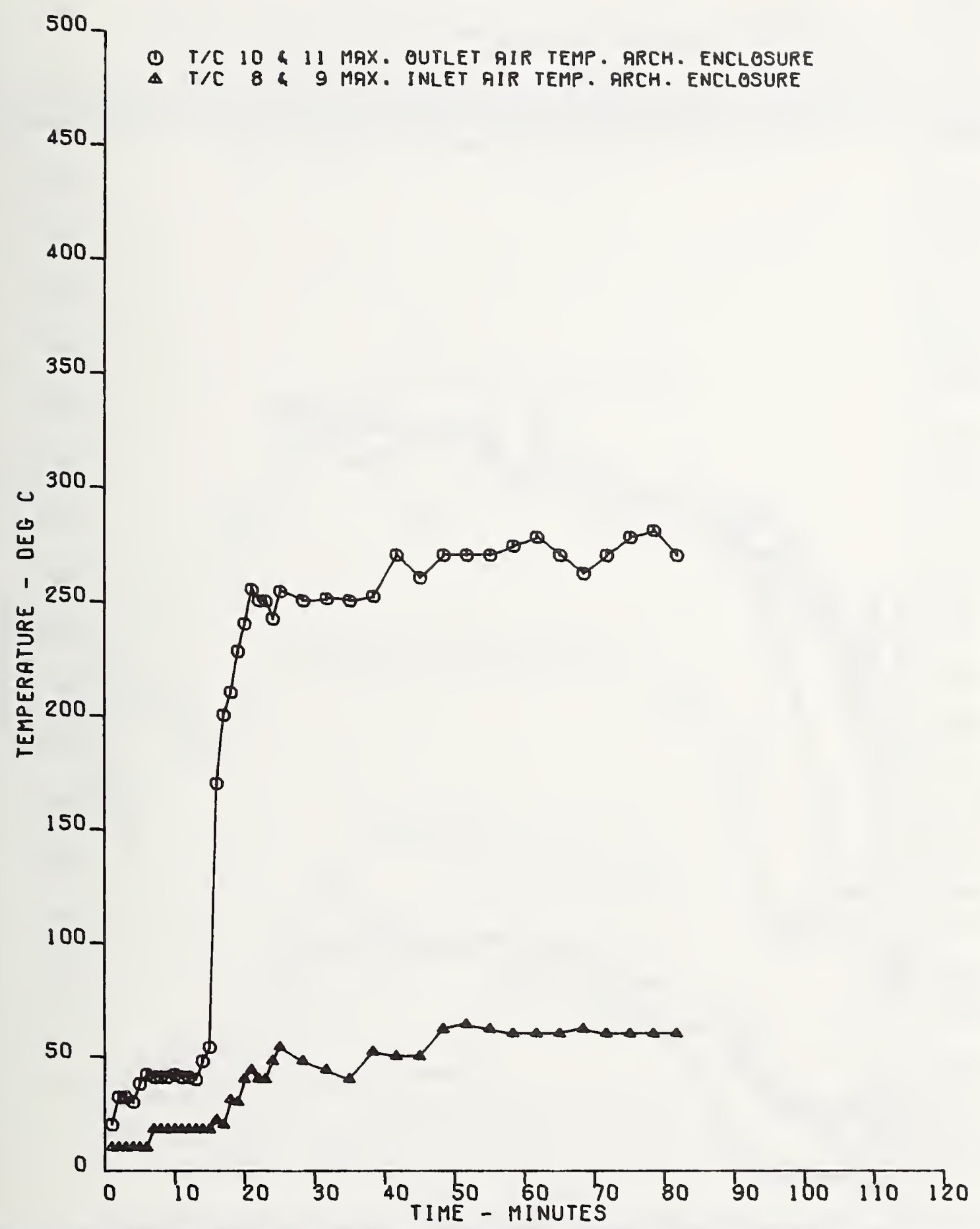

FIG. 23 TEST 5165 INCH WOVEN GLASS FABRIC - AIR TEMPERATURES ARCHITECTURAL ENCLOSURE 


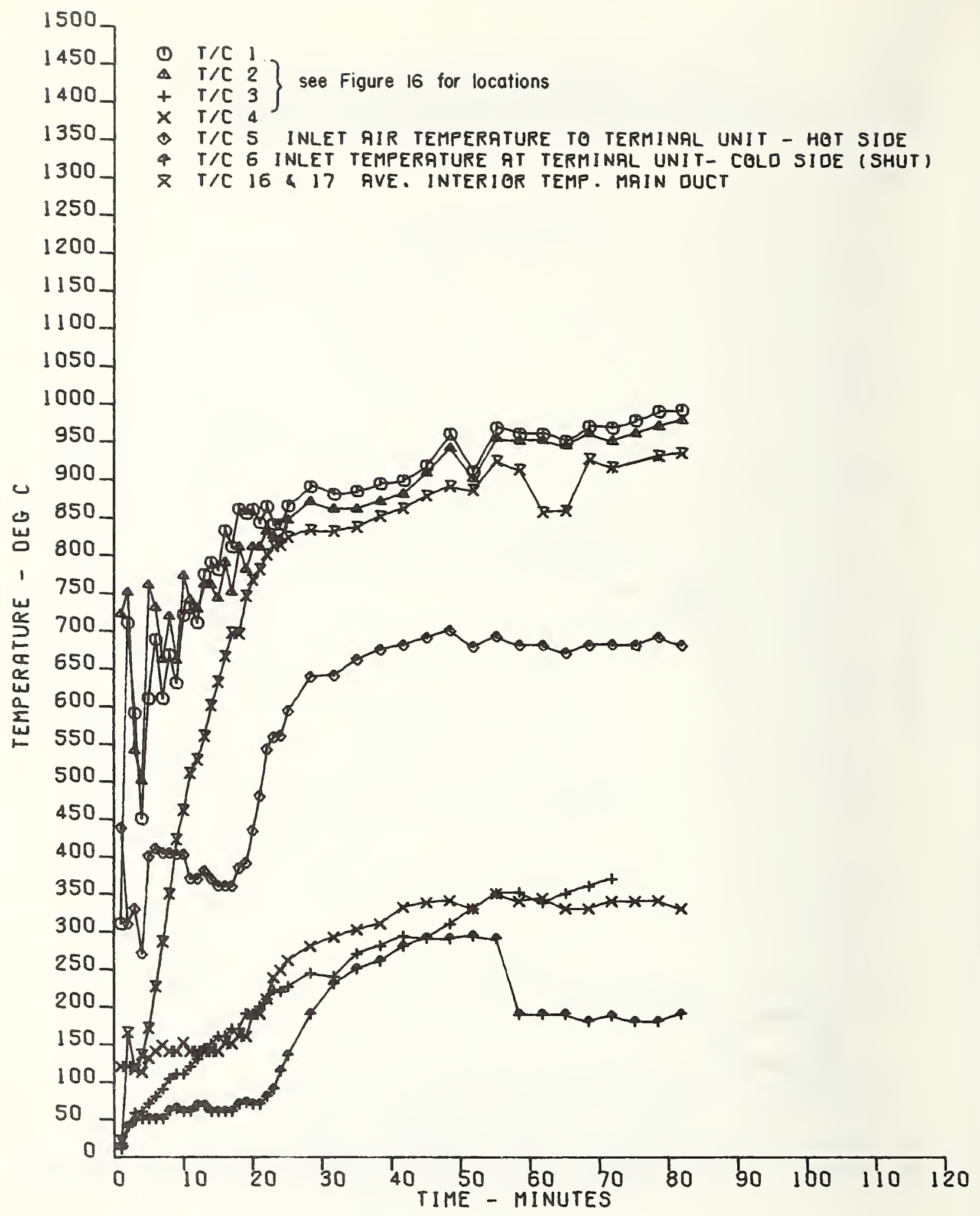

FIG. 24 TEST 5165 INCH GALV STEEL * TEMPERATURES ALONG CONNECTOR 


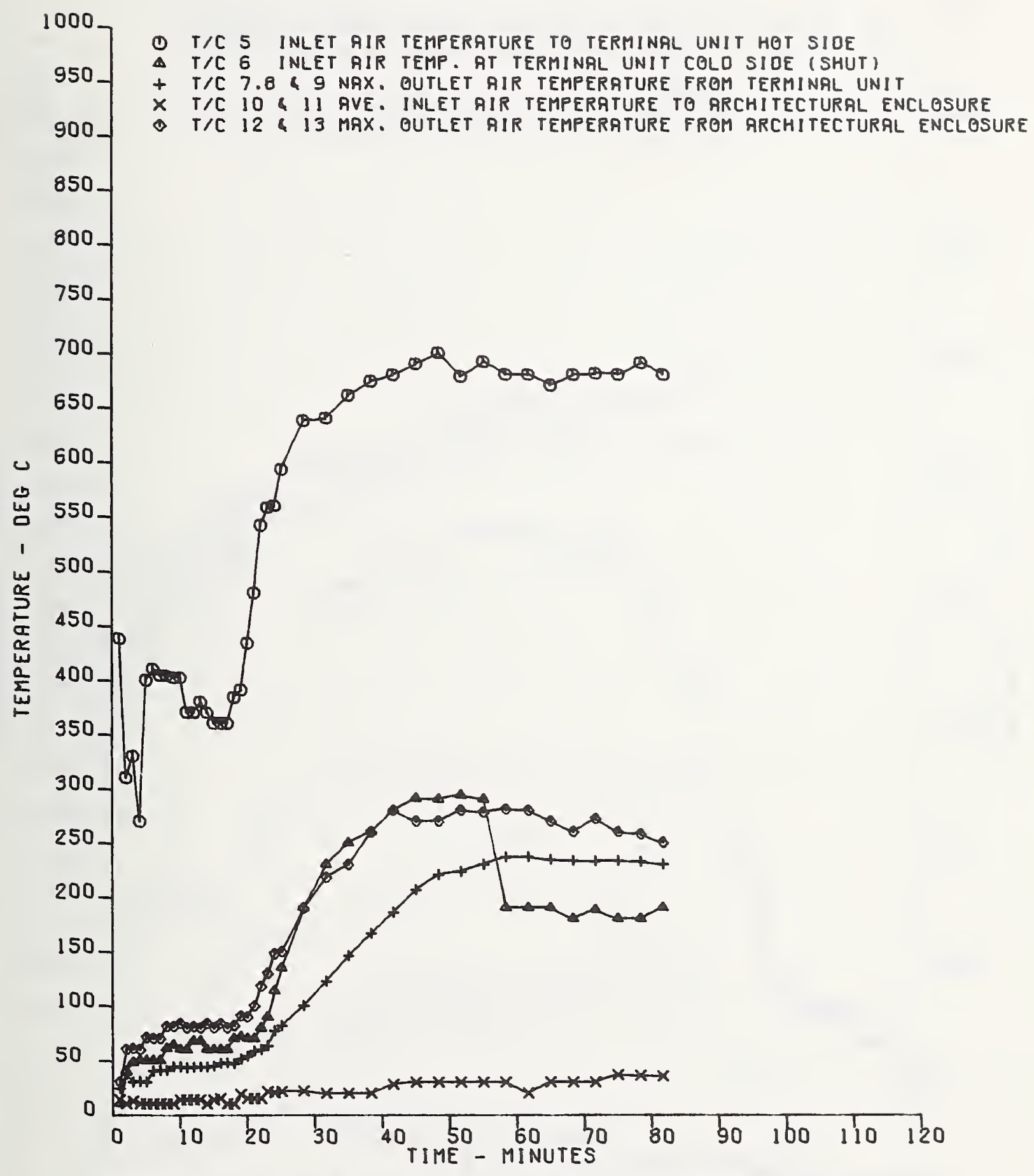

FIG. 25 TEST 5165 INCH GALV STEEL - TEMPERATURES ALONG TERMINAL UNIT AND ARCHITECTURAL ENCLOSURE 


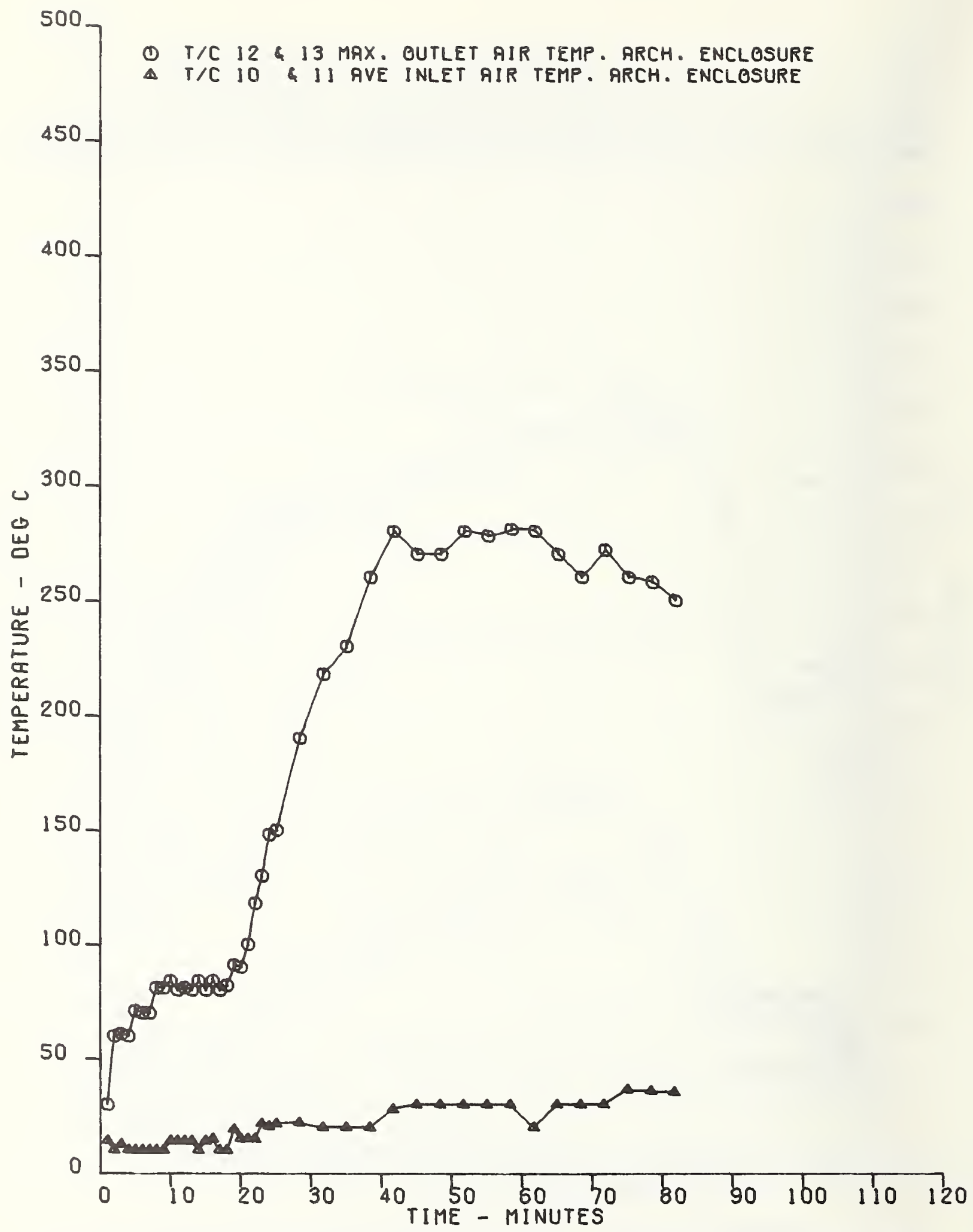

FIG. 26 TEST 5165 INCH GALV STEEL - AIR TEMPERATURES ARCHITECTURAL ENCLOSURE 




FIG 27 TEST 5166 INCH GALV STEEL - TEMPERATURES ALONG CONNECTOR 


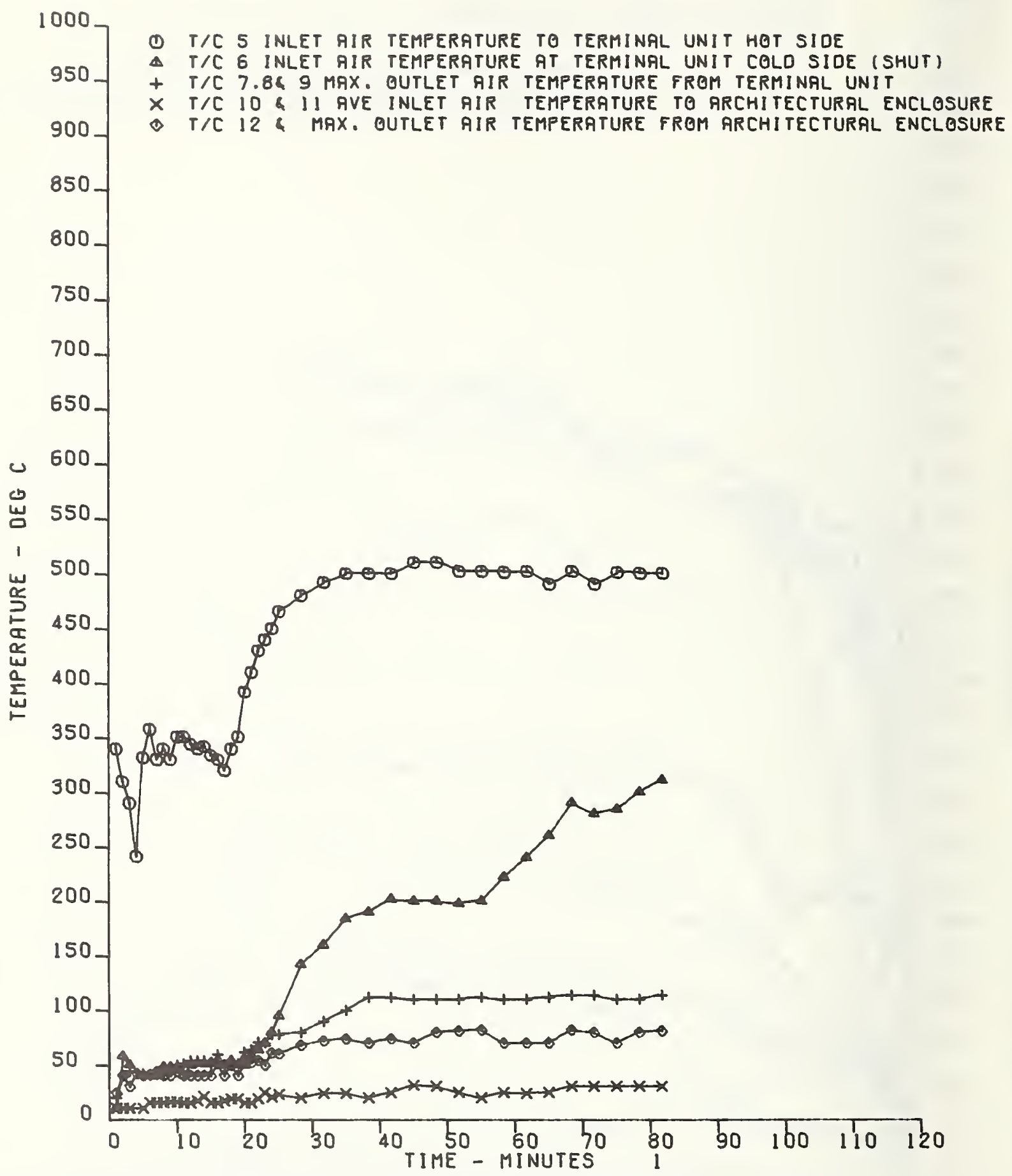

FIG. 28 TEST 5166 INCH GALV STEEL - TEMPERATURES ALONG TERMINAL UNIT AND ARCHITECTURAL ENCLOSURE 


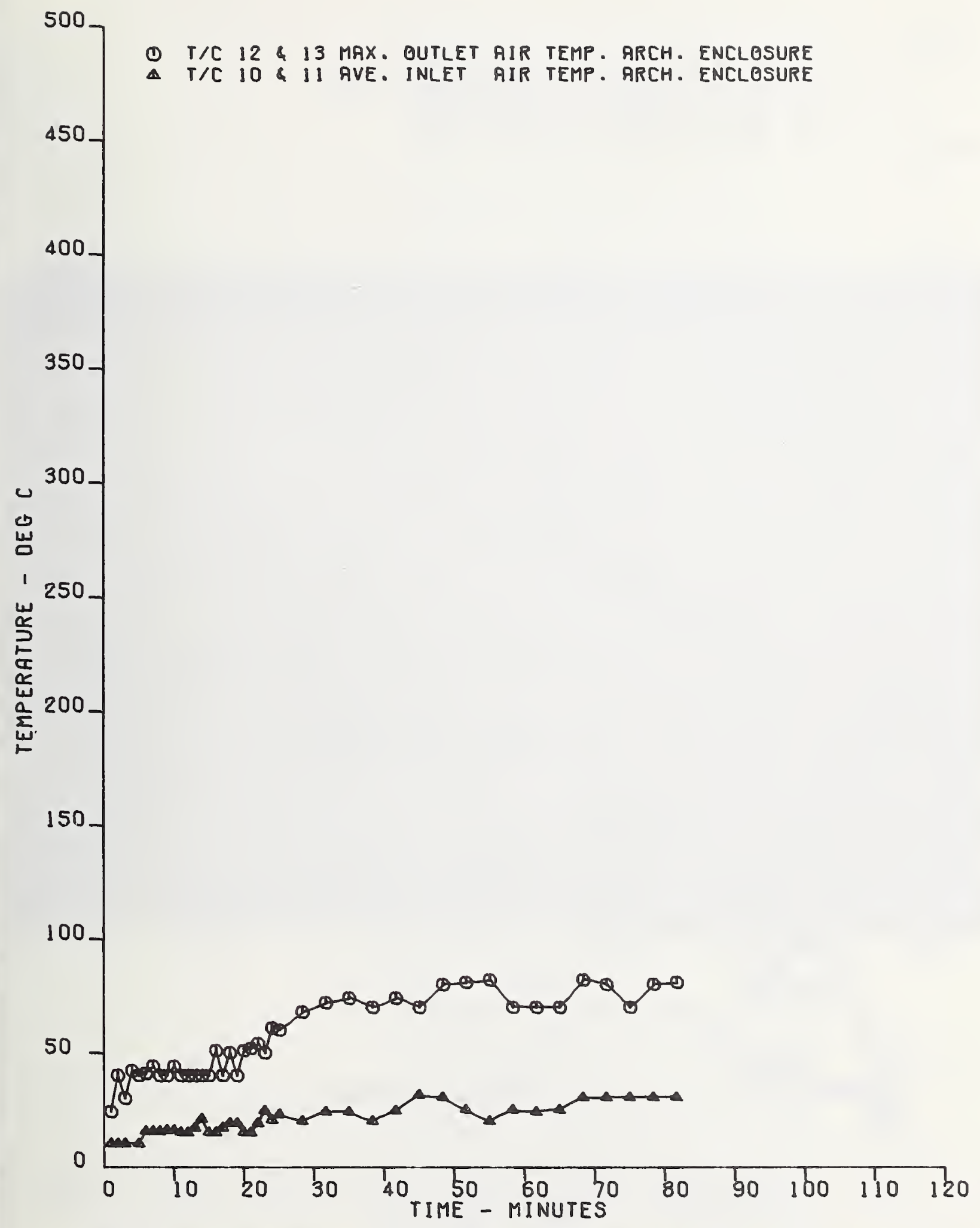

FIG. 29 TEST 5166 IN GALV STEEL “AIR TEMPERATURES ARCHITECTURAL ENCLOSURE 


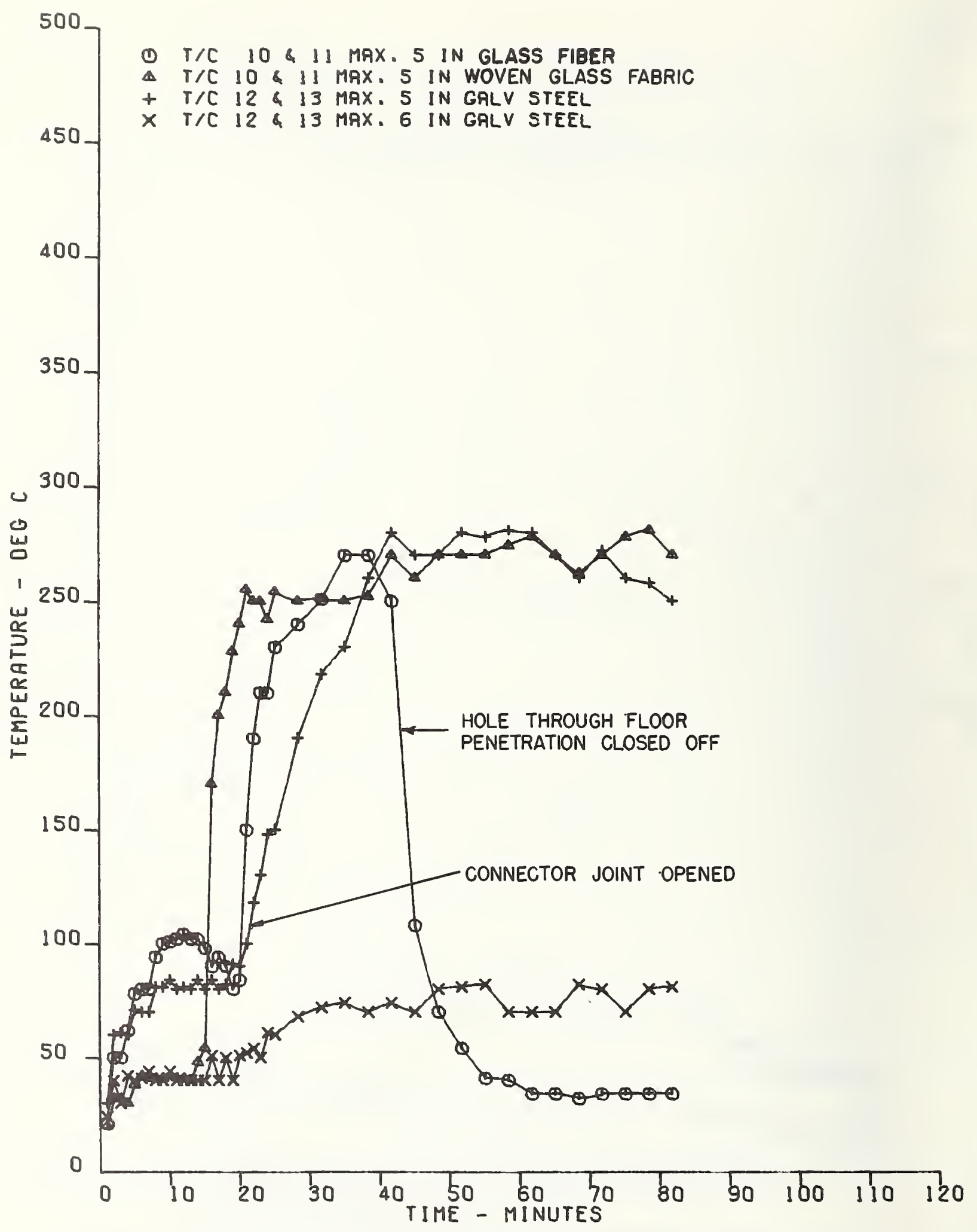

FIG. 30 TEST 516 COMPARISON OF OUTLET AIR TEMP. ON ARCH. ENCLOSURES 
Figure 31 - Separation of 5 inch Steel Connector from Main Duct 







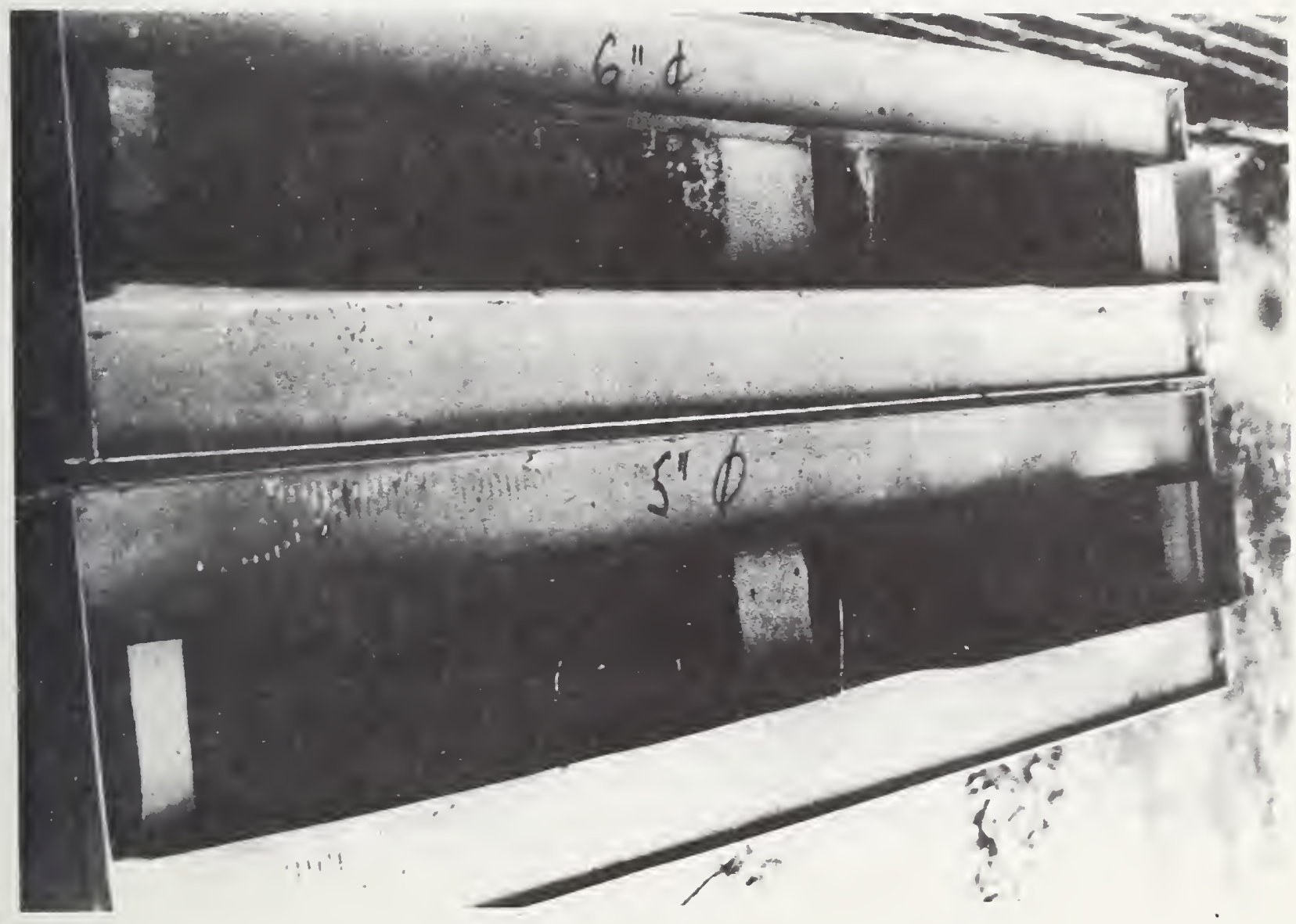

Figure 33 - Comparison of Charring Inside the ONYP Terminal Units for the 5 and 6 Inch Diameter Steel Assemblies 
NBS-114A (REV. 7-73) U.S. DEPT. OF COMM.
BIBLIOGRAPHIC DATA
SHEET

4. TITLE AND SUBTITLE
1. PUBLICATION OR REPORT NO. NBSIR 73-267 2. Gov't Accession
No.

3. Recipient's Accession No.

5. Publication Date

Report of Fire Tests on Flexible Connectors in HVAC Systems

7. AUTHOR(S)

Lionel A. Issen

9. PERFORMING ORGANIZATION NAME AND ADDRESS

\section{NATIONAL BUREAU OF STANDARDS DEPARTMENT OF COMMERCE WASHINGTON, D.C. 20234}

6. Performing Organization Code

8. Performing Organ. Report No. NBSIR 73-267

10. Project/Task/Work Unic No. 4619360

11. Contract/Grant No.

13. Type of Report \& Period Covered

Final Report

14. Sponsoring Agency Code

15. SUPPLEMENTARY NOTES

16. ABSTRACT (A 200-word or less factual summary of most significant information. If document includes a significant bibliography or literature survey, mention it here.)

The contemporary high rise building with its control air conditioning system and high content of synthetic materials presents a higher hazard than those erected prior to 1950. The ability of the duct work to resist fire breaking into it and spreading through the duct system is an important factor affecting the integrity of the building Since they penetrate fire barriers, the flexible connectors between the main ducts and the terminal units are important elements in maintaining the desired fire resistance. Flexible connectors made of four different materials (aluminum, galvanized steel, felted fiberglass and woven fiberglass fabric) and two attachment techniques were subjected to fire tests in accordance with ASTM E119. The results show that the materials of the connectors must withstand the fire exposure, the connectors must remain tightly attached to the main duct, and the penetrations through the fire barrier must be suitably blocked in order to prevent fire from breaking into the duct system. The tests also showed that rubber and plastic materials in the terminal units can produce significant amounts of irritating smoke.

17. KEY WORDS (six to twelve entries; alphabetical order; capitalize only the first letter of the first key word unless a proper name; separated by semicolons) Aluminum; ductwork; fabric; fiberglass; fire tests; high rise buildings; HVAC systems; steel; terminal units.
18. AVAILABILITY
$\mathrm{X}\urcorner$ Unlimited

For Official Distribution. Do Not Release to NTIS

Order From Sup. of Doc., U.S. Government Printing Office Washington, D.C. 20402 , SD Cat. No. CI3

$\square$ Order From National Technical Information Service (NTIS) Springfield, Virginia 22151
19. SECURITY CLASS (THIS REPURT)

UNCL ASSIFIED

20. SECURITY CLASS (THIS PAGE)

UNCLASSIFIED
21. NO. OF PAGES 56

22. Price 


